\title{
Imidazole as a Promising Medicinal Scaffold: Current Status and Future Direction
}

\author{
Sahar S Alghamdi (1D ${ }^{1,2}$ \\ Rasha S Suliman (1D) ${ }^{1,2}$ \\ Khlood Almutairi ${ }^{1}$ \\ Khawla Kahtani' \\ Dimah Aljatli' \\ 'College of Pharmacy, King Saud bin \\ Abdulaziz University for Health Sciences, \\ Riyadh, Kingdom of Saudi Arabia; \\ ${ }^{2}$ Medical Research Core Facility and \\ Platforms, King Abdullah International \\ Medical Research Center (KAIMRC), \\ Ministry of National Guard Health \\ Affairs, Riyadh, Kingdom of Saudi Arabia
}

Correspondence: Rasha S Suliman Tel +966 I I 4299999 Ext 99570

Email sulimanr@ksau-hs.edu.sa

\begin{abstract}
Various imidazole-containing compounds have been tested for their medical usefulness in clinical trials for several disease conditions. The rapid expansion of imidazolebased medicinal chemistry suggests the promising and potential therapeutic values of imidazole-derived compounds for treating incurable diseases. Imidazole core scaffold contains three carbon atoms, and two nitrogen with electronic-rich characteristics that are responsible for readily binding with a variety of enzymes, proteins, and receptors compared to the other heterocyclic rings. Herein, we provide a thorough overview of the current research status of imidazole-based compounds with a wide variety of biological activities including anti-cancer, anti-microbial, anti-inflammatory and their potential mechanisms including topoisomerase IIR catalytic inhibition, focal adhesion kinase (FAK) inhibition, c-MYC G-quadruplex DNA stabilization, and aurora kinase inhibition. Additionally, a great interest was reported in the discovery of novel imidazole compounds with anti-microbial properties that break DNA double-strand helix and inhibit protein kinase. Moreover, antiinflammatory mechanisms of imidazole derivatives include inhibition of COX-2 enzyme, inhibit neutrophils degranulation, and generation of reactive oxygen species. This systemic review helps to design and discover more potent and efficacious imidazole compounds based on the reported derivatives, their ADME profiles, and bioavailability scores that together aid to advance this class of compounds.
\end{abstract}

Keywords: imidazole, apoptosis, kinase inhibitors, tubulin polymerization, topoisomerase II

\section{Introduction}

In the last century, nitrogen-based heterocycles, particularly the imidazole ring which was discovered in the 1840 s, attracted many researchers as this core scaffold demonstrated promising anti-cancer, anti-microbial, and anti-inflammatory activities. ${ }^{1}$ The structural features of the imidazole ring enhance their ability to form multiple drug-ligand interactions via hydrogen bonds, van der Waals, and hydrophobic forces. ${ }^{2}$ Moreover, the imidazole core scaffold is a part of several naturally derived compounds, such as histamine, histidine, biotin, alkaloids, and nucleic acid, and a part of multiple classes of FDA-approved drugs. Because of their important properties as therapeutics, fused imidazole derivatives have held a prominent role in the medical field. Methotrexate, Metronidazole, and Omeprazole are the current imidazole derivatives available on market as anticancer, anti-microbial, and anti-inflammatory agents, respectively. Nevertheless, these drugs have shown painful and unacceptable side effects that caused treatment failure. ${ }^{3}$ To discover potent compounds with better safety profiles, Imidazole-based compounds are under intensive scientific exploration as these derivatives have 
achieved amazing progression in medicinal chemistry research. The literature summarized in this review aids in the design and development of novel and highly potent compounds with less harmful side effects for the treatment of lethal human diseases.

\section{Anti-Cancer Properties of Imidazole Derivatives}

Cancer is the second major cause of death after cardiac disease nationally and internationally. The annual number of new cases is estimated to be 439.2 per 100,000 people. $^{4}$ At the current global rate, the estimated number of cancer is rapidly increasing and predicted to reach approximately 27.5 million new cancer cases per year by $2040 .{ }^{5}$ Until today, the detailed mechanism of cancer is not fully understood and with a simple definition, it is considered to be a genetic disease that starts with abnormal and continuous cell growth, with the chance of metastasis. ${ }^{6}$ The current chemotherapeutic agents available such as Methotrexate, Etoposide, and Paclitaxel demonstrated potent activity and to some extent, good survival rates, however, several challenges need to be overcome, such as drug resistance, toxicity, and intolerable side effects. ${ }^{7}$ Thus, a new rationale for anticancer agents should be investigated to discover new targeted therapy with lower systemic side effects. ${ }^{8}$ According to some reported studies, imidazole has the potential to overcome the unresolved disadvantages of currently available clinical drugs and could be utilized as a chemical scaffold for novel anticancer agents with several potential mechanisms of action. Therefore, in the following sections, we will be discussing the multiple mechanisms of several imidazole derivatives that possess anti-cancer activity.

In this regard, Baviskar et al have investigated five imidazole derivatives that demonstrated potent catalytic inhibition of DNA and authors believed that these compounds were highly specific to the Topoisomerase IIR with improved potency compared to Etoposide and 5-fluorouracil in kidney cancer cells. ${ }^{9}$ An MTT assay was performed to examine the cytotoxic activity in both kidney cancer cells (HEK 293) and Vero cells. After 48 hours of treatment, the cell viability of HEK 293 decreased significantly compared to Vero cells. As a result, compound C1 demonstrated the highest potency with $\mathrm{LC}_{50}$ of $25 \mu \mathrm{M}$ in HEK 293 cells and $62 \mu \mathrm{M}$ in Vero cells.

Additionally, to seek more powerful and lower toxic anticancer agents, six imidazole compounds were synthesized by Zhao et al and tested in vitro. Among them, compound C2 showed higher activity against breast cancer cells (MCF-7) with $\mathrm{IC}_{50}$ of $0.75 \mu \mathrm{M}$ compared to Doxorubicin. Compound $\mathrm{C} 2$ had potent anticancer activity, with $\mathrm{IC}_{50}$ of $4.37 \mu \mathrm{M}$, against lung cancer cells (A549) and authors concluded that these derivatives mediated anti-cancer activity via inducing apoptosis and suppressing cancer cell proliferation. ${ }^{10}$ Moreover, using in vitro experiments, Dao et al evaluated twenty-six synthesized imidazole compounds, and study results revealed that compound $\mathrm{C} 3$ showed the greatest inhibition with $\mathrm{IC}_{50}$ values of $50 \mu \mathrm{M}$ against cancer cells expressing high levels of focal adhesion kinase (FAK), including Brain (U87-MG), Colon (HCT-116), Breast (MDA-MB)-231, and Prostate (PC-3) cancer cell lines. ${ }^{12}$

Roopashree et al synthesized new series of imidazole derivatives to investigate the antiproliferative activity on Hela cells and with Sorafenib as a reference drug. The results showed that compound $\mathrm{C} 4$ was a very potent inhibitor with an $\mathrm{IC}_{50}$ of $25.3 \mu \mathrm{M}$. Using an in-vivo model, $\mathrm{C} 4$ was significantly able to decrease angiogenic properties against Ehrlich ascites tumor (EAT) bearing mice. ${ }^{14}$ In 2011, Alkahtani et al synthesized several imidazole derivatives to identify the anti-proliferative activity on the colon (HCT-116) and breast (MCF-7) cancer cells. It was concluded that compound $\mathrm{C} 5$ has anti-proliferative activity by inhibiting cyclin-dependent kinase 6 (CDK6) and inducing apoptosis on myeloid cell leukemia 1 (Mcl-1) protein. ${ }^{15}$

In another study, Chung et al found that only eleven compounds among the twenty-six imidazole derivatives showed good activity against human umbilical vein endothelial cells (HUVECs) and smooth muscle cells (SMCs), using mycophenolic acid as a standard control. The results suggested that only three compounds, including compound $\mathrm{C} 6$, activated the p38 signaling pathway, and were selective inhibitors of endothelial cell proliferation specifically for human umbilical vein endothelial cells (HUVECs). ${ }^{16}$ Using in vitro experiments, Xue et al investigated twenty compounds for their cytotoxicity, compound $\mathrm{C} 7$ exhibited equal or more potent cytotoxic activity compared to docetaxel in a dose-dependent manner. Additionally, $\mathrm{C} 7$ arrested the cell cycle on the S phase at $0.01 \mu \mathrm{M}$, and induced cell apoptosis at $0.1-1.0 \mu \mathrm{M}$. Moreover, an additional amino group at the $\mathrm{C}-3$ position on the $\mathrm{B}$ ring was beneficial for potency against human myeloid leukemia (HL-60) and human myeloid leukemia (K562) cells. Using in vivo model, compound C7 showed significant anticancer activity on murine S-180 which was similar to cyclophosphamide (CTX), and higher inhibition on murine $\mathrm{H}-22$ tumor-bearing models was observed. ${ }^{17}$ 
Another study reported that compound $\mathrm{C} 8$ bearing imidazole ring demonstrated the highest anti-proliferative activity with an average $\mathrm{IC}_{50}$ value of $7.219 \mu \mathrm{M}$ against four cancer cells, including MCF-7, H1299, HeLa, and B16F10. The result suggested that $\mathrm{C} 8$ has a dose-dependent effect in inhibiting tubulin polymerization and suppressing the cell cycle in the $\mathrm{G} 2 / \mathrm{M}$ phase. ${ }^{21}$

On investigating the cytotoxicity of imidazole compounds against cervical cancer, it was reported that $\mathrm{C} 9$ possesses a potent anticancer activity with $\mathrm{IC}_{50}$ of 0.08 $\mu \mathrm{M}$, which was comparable to 5-fluorouracil with $\mathrm{IC}_{50}$ $0.09 \mu \mathrm{M}$. The potential mechanism of C9 was via suppressing the cell cycle at the G1 phase and inducing apoptosis. Furthermore, compound $\mathrm{C} 9$ exhibited a remarkable inhibition effect on the carbonic anhydrase IX enzyme with an $\mathrm{IC}_{50}$ of $0.12 \mu \mathrm{M}$ comparable to Dorzolamide HCL with $\mathrm{IC}_{50}$ of $0.09 \mu \mathrm{M}$, as standard drug. ${ }^{22}$ Meenakshisundaram et al draw our attention to the role of imidazole derivatives on estrogen receptors by screening 30 compounds, remarkably compound $\mathrm{C} 10$ was the most potent derivative with higher anticancer activity against breast cancer cells relative to Adriamycin, with $\mathrm{GI}_{50} 0.3$ and $\mathrm{GI}_{50} 0.51 \mu \mathrm{M}$, respectively. The addition of the nitrogen group in the imidazole ring was beneficial for improving cytotoxic activity. Using in vivo model, C10 demonstrated similar anticancer activity comparable to Tamoxifen. The authors concluded that $\mathrm{C} 10$ could bind to the estrogen receptors (ERs) as consequence the receptors dimerized in the breast cancer cells that resulted in cytotoxicity and apoptosis. ${ }^{18}$

Recently, Wu et al synthesized and evaluated six derivatives that demonstrated superior anticancer activity against a variety of tumor cells, specifically nasopharyngeal carcinoma (CNE-1) cells. Compound $\mathrm{C} 11$ yielded an $\mathrm{IC}_{50}$ of $1.1 \mu \mathrm{M}$ with more potent antitumor activity through stabilizing DNA c-MYC G-quadruplex relative to Doxorubicin and with less harmful side effects against the human normal cell line. ${ }^{19}$ In another attempt, Fan et al synthesized and experimentally screened twenty imidazole derivatives. Among them, compound $\mathrm{C} 12$ had the highest anti-proliferative activity against breast cancer (MDA-MB -231), prostate cancer ( $\mathrm{PC} 3$ ), and neuroblastoma ( $\mathrm{SH}-$ SY5Y) cells, with an $\mathrm{IC}_{50}$ value of $0.38,1.09$, and $0.77 \mu \mathrm{M}$, respectively, through inhibition of aurora kinase that resulted in cell apoptosis. ${ }^{20}$

According to a recent report conducted by Ali et al, the synthesized imidazole derivatives were investigated for potential anti-cancer activity on human cancer cells using Dabrafenib as a reference agent. The results showed that between nineteen compounds, compound $\mathrm{C} 13$ has the greatest activity against NCI60 human cancer cell line and melanoma with mean $\mathrm{IC}_{50}$ of 2.4 and $1.8 \mu \mathrm{M}$, respectively. Compound $\mathrm{C} 13$ possesses a potential anti-cancer activity against both NCI 60 and melanoma human cancer cell lines via BRAF ${ }^{\mathrm{V} 600 \mathrm{E}}$ kinase inhibition. ${ }^{23}$

In a work reported in 2020, anti-cancer activity of a newly synthesized novel imidazole derivatives was investigated against multiple cancer cell lines including human colon carcinoma (Caco-2 and HCT-116), human cervical carcinoma (HeLa), and human breast adenocarcinoma (MCF-7). Compound C14 demonstrated the highest cytotoxic activity against all cancer cell lines specifically against MCF-7 with $\mathrm{IC}_{50} 0.38 \mu \mathrm{M}$. Moreover, most of the synthesized compounds were non-carcinogenic. Overall, compound $\mathrm{C} 14$ showed the best cytotoxic activity through the inhibitory effect of glycogen synthase kinase 3 beta (GSK-3 $\beta$ ) and could be a potential anti-cancer agent with less toxicity. ${ }^{24}$

On the other hand, several studies had promising results of imidazole compounds as anticancer agents but unfortunately, their mechanisms of action were not determined. As seen in Chen et al study which investigated seventeen imidazole derivatives with potential antiproliferative activity in two cell lines. Among them, compound $\mathrm{C} 15$ demonstrated $\mathrm{IC}_{50}$ of 16.1 and $31.6 \mu \mathrm{M}$ in human (A375) and mouse (B16) melanoma cells, respectively. ${ }^{11}$ Moreover, Sarkarzadeh et al have shown that among forty compounds, $\mathrm{C} 16$ demonstrated promising anti-proliferative activities compared to Cisplatin which emphasizes the importance of imidazole derivatives particularly on the Jurkat cell line. ${ }^{13}$ Besides, a study carried out by Zhang et al evaluated the anticancer activity of synthesized pyrrole-imidazole series against human pancreatic cancer cell lines (PANC and ASPC-1) and prostate cancer cells. The results showed that compound $\mathrm{C} 17$ has the highest anti-cancer activity with more selectivity towards PANC and ASPC-1 relative to prostate cancer cells with $\mathrm{IC}_{50}$ of 0.063 and $0.062 \mu \mathrm{M}$, respectively. ${ }^{25}$ All the discussed Imidazole derivatives with anti-cancer activities are summarized in Table 1.

\section{Anti-Microbial Properties of Imidazole Derivatives}

For several years, humans have been continuously exposed to different pathogens on daily basis and such invasive microbial infections are considered major problems particularly in 
Table I The Anti-Cancer Activities of Imidazole Derivatives Using Several Cancer Cell Lines

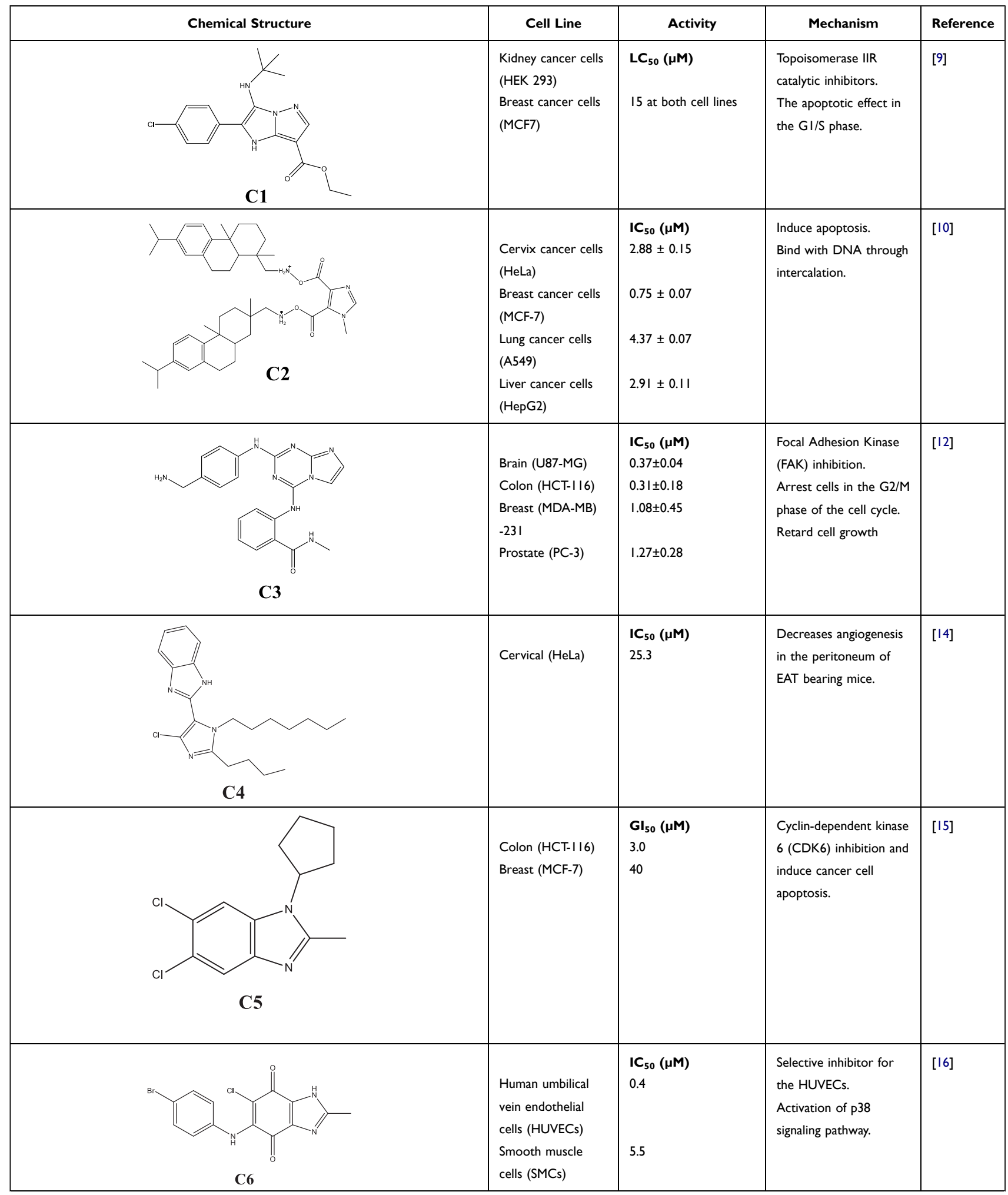

(Continued) 
Table I (Continued).

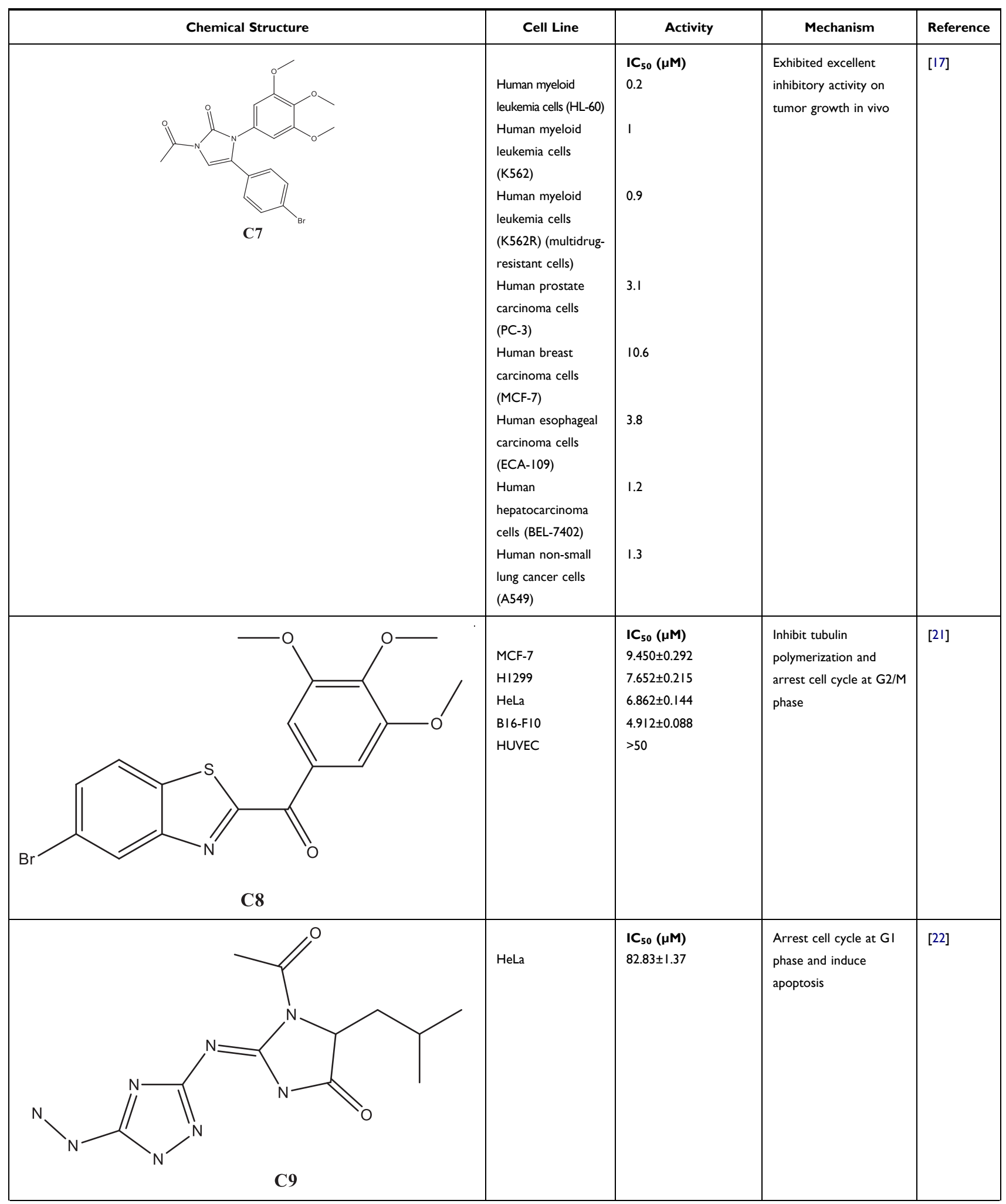

(Continued) 
Table I (Continued).

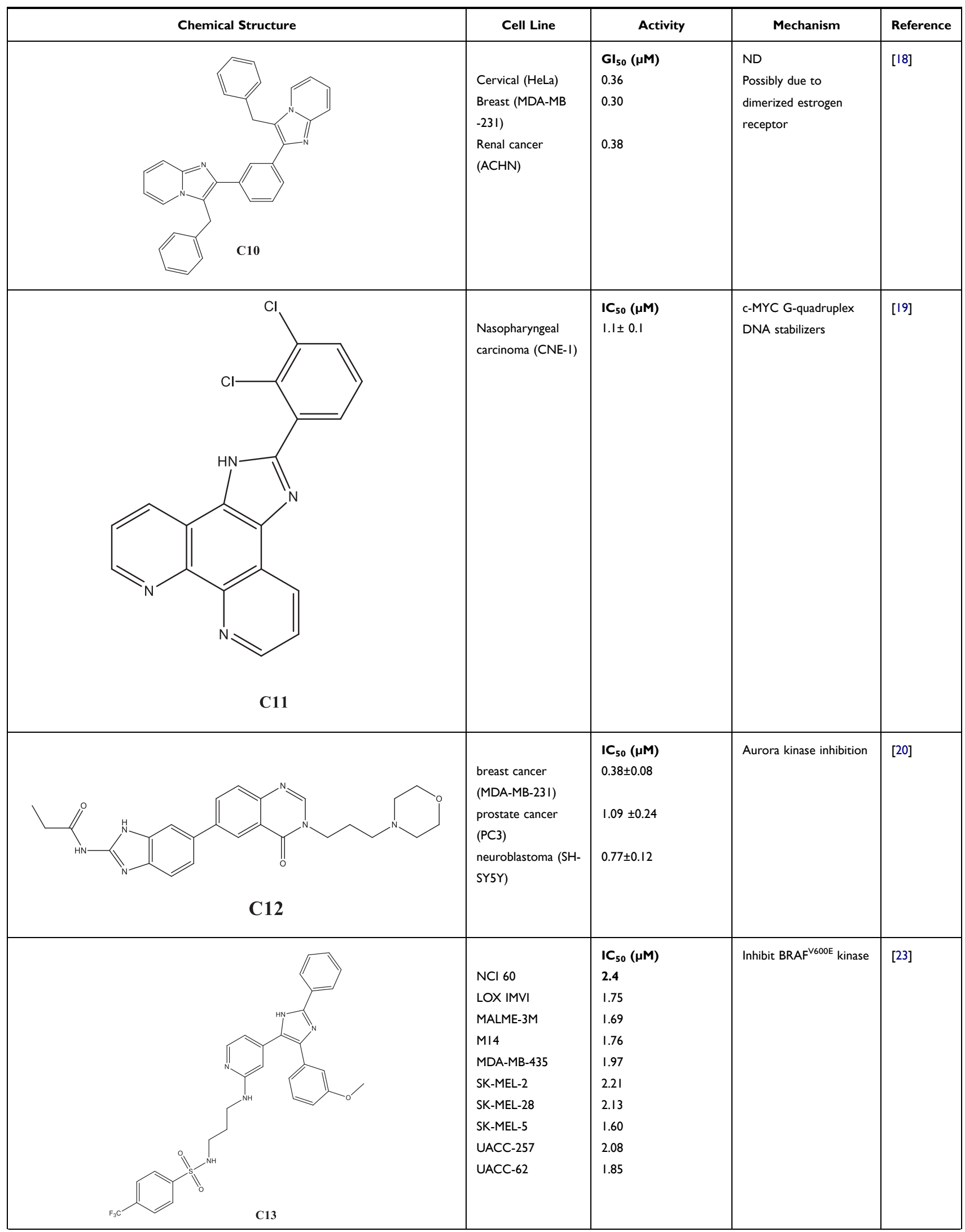

(Continued) 
Table I (Continued).

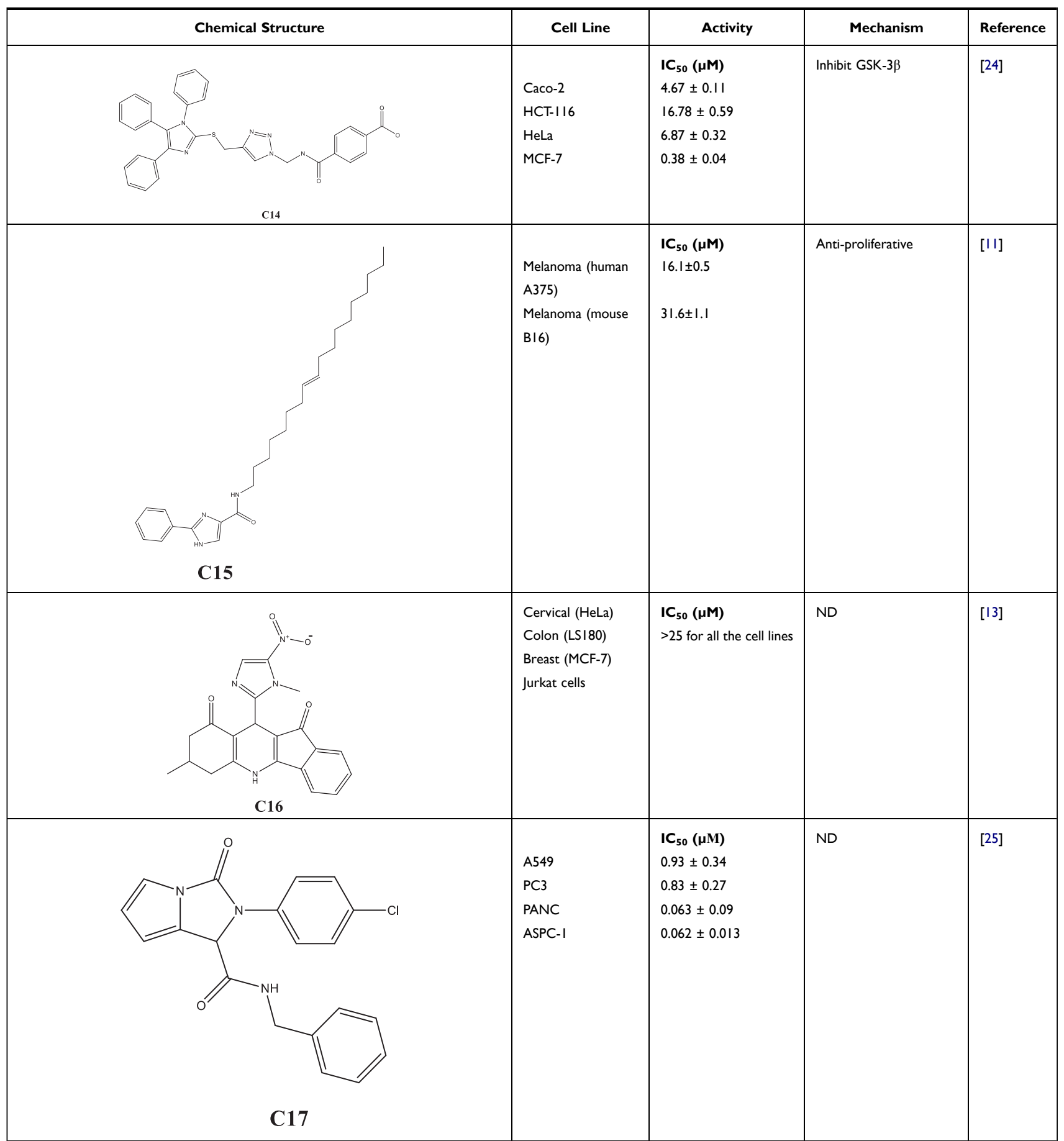

Note: Values are means of three experiments.

Abbreviation: $\mathrm{LC}_{50}$, The concentration required to kill half the cells in the cell culture; $\mathrm{IC}_{50}$, Compound concentration required to inhibit tumor cell proliferation by $50 \%$; $\mathrm{Gl}_{50}$, The concentration of drug causing $50 \%$ inhibition of cell growth; ND, Not determined.

immunocompromised people. $^{26}$ Infectious diseases were increasingly recognized as a serious worldwide public health concern and for this reason, tracking and reporting on antibiotic resistance in a recorded number of nations, making a significant step forward in the global battle against drug resistance and the evidence showing that the medications that were used for treatment are increasingly resistant to a various number of bacterial infections. ${ }^{27,28}$ 
The wide use of antimicrobial agents in the treatment of common infectious diseases such as urinary tract infections and abdominal tract infections suggests that the world is running out of effective strategies to deal with these infectious diseases. For example, in 33 countries, the resistance rate of ciprofloxacin ranged from $8.4 \%$ to $92.9 \%$. Currently, in 2021 the world health organization is worried that the excessive use of antibiotics during the COVID-19 pandemic will further intensify the rise in antimicrobial resistance. ${ }^{28}$ In this century, the growth of antimicrobial resistance expanded, and new antimicrobial agents that are selective, potent, and less harmful compared to current drugs will be needed to eliminate the life-threatening invasive infections in clinical care. ${ }^{29}$ One of the key aspects to discover new agents is to determine the Structure-Activity Relationships (SAR) of a chemical scaffold, followed by structural modifications to optimize some of the biological activities at a specific target. Herein, we summarized the most potent imidazole derivatives as potential antimicrobial agents based on their SAR and essential structural features.

As reported by Ansari et al, the authors synthesized twentytwo imidazole derivatives to investigate and determine the antibacterial activity. All the synthesized compounds displayed good activity against Gram-positive but low activity against Gramnegative bacteria with the MIC ranging from 4 to 64 $\mu \mathrm{M}$ compared to Ampicillin and Ciprofloxacin as standard drugs. Among the twenty-two compound, M18 illustrated remarkable antibacterial activity with MIC $2 \mu \mathrm{M}$ against Staphylococcus aureus as shown in Table 2. Besides, some of the synthesized compounds demonstrated good to moderate antifungal activity. However, compound M18 was found to be equipotent as Amphotericin B against Candida Albicans and A. Flavus. The author concluded that as the number of carbon atoms in the side chain at the 2-position of the oxadiazole heterocyclic ring increases, the antibacterial activity against Candida Albicans increases. ${ }^{30}$

An additional study was conducted in 2009, screened twenty compounds against two Gram-positive, two Gramnegative bacteria, and five fungus strains. The antibacterial screening demonstrated that compound M19 showed good inhibitory activity against Escherichia coli, S. typhimurium, B. subtilis, and Staphylococcus aureus with a diameter of zone of inhibition 19, 17, 20, and $21 \mathrm{~mm}$, respectively, compared to Chloramphenicol as a standard drug. Furthermore, it seemed that the antibacterial and antifungal activity both depend on the heterocyclic moiety, not only that but also, the activity was enhanced by the presence of nitro and chlorine substituents on the benzimidazole moiety. Besides, the twenty compounds were also tested for antifungal activity in another series of experiments. Moreover, compound M20 showed good antifungal activity against C. Albicans, H. oryzae, A. Niger, T. viridae, and Penicillium species with zone inhibition diameter of $18,15,15,10$, and $19 \mathrm{~mm}$, respectively. Nystatin was used as the standard drug. Unfortunately, the diameter of the inhibition zone against $T$. viridae was considerably lower than the other fungal strain in this study. ${ }^{31}$

In this regard, Pieczonka et al reported in vitro activity of 3-oxido-1H-imidazole-4-carbohydrazides against 4 Grampositive strains, 4 Gram-negative strains, and Candida albicans as fungal species. The authors used vancomycin and oxacillin as reference agents for Gram-positive, and chloramphenicol for Escherichia coli. The results showed potent antibacterial activity of compound M21 against some strains, indicate that the 5-nitrofuryl group was essential for antibacterial activity. Eventually, compound M21 had antimicrobial properties due to nitro-substituted furan ring which can be considered as an essential moiety in antibacterial activity. ${ }^{32}$

Knowing the mechanism of action of new potential anti-microbial agents can provide more information regarding the safety of compounds by understanding their effect on the human body however, two studies reported the antibacterial activity of imidazole derivatives without investigating the mechanism of action.

A good example of this is the newly synthesized imidazole derivatives benzimidazole-1,2,3-triazole-sulfonamide hybrids that were tested for antimicrobial activity. In this study, four bacterial strains Bacillus cereus, Staphylococcus aureus, E. coli, and $P$. aeruginosa were utilized with ciprofloxacin as a reference agent. The result demonstrated that compound M22 was the most potent antimicrobial derivative against the mentioned strains with MIC range from 32 to $64 \mu \mathrm{M} .{ }^{33}$ A recent report was done by Daraji et al, described the antibacterial efficacy of imidazole derivatives against E. coli, P. aeruginosa, S. aureus, and S. pyogenes. Among all the compounds, compound M23 was found to be active against all the strains with broad-spectrum antibacterial activity against the Extended-spectrum beta-lactamase (ESBL), Vancomycin-resistant Enterococcus (VRE), and Methicillin-resistant Staphylococcus aureus (MRSA) strains. ${ }^{34}$ All the discussed Imidazole derivatives with antimicrobial properties are summarized in Table 2.

\section{The Anti-Fungal Properties of Imidazole Derivatives}

Imidazole derivatives possessed several pharmacological activities, one of these is antifungal property which was also 
Table 2 The Anti-Microbial Activities of Imidazole Derivatives Using Several Microorganisms

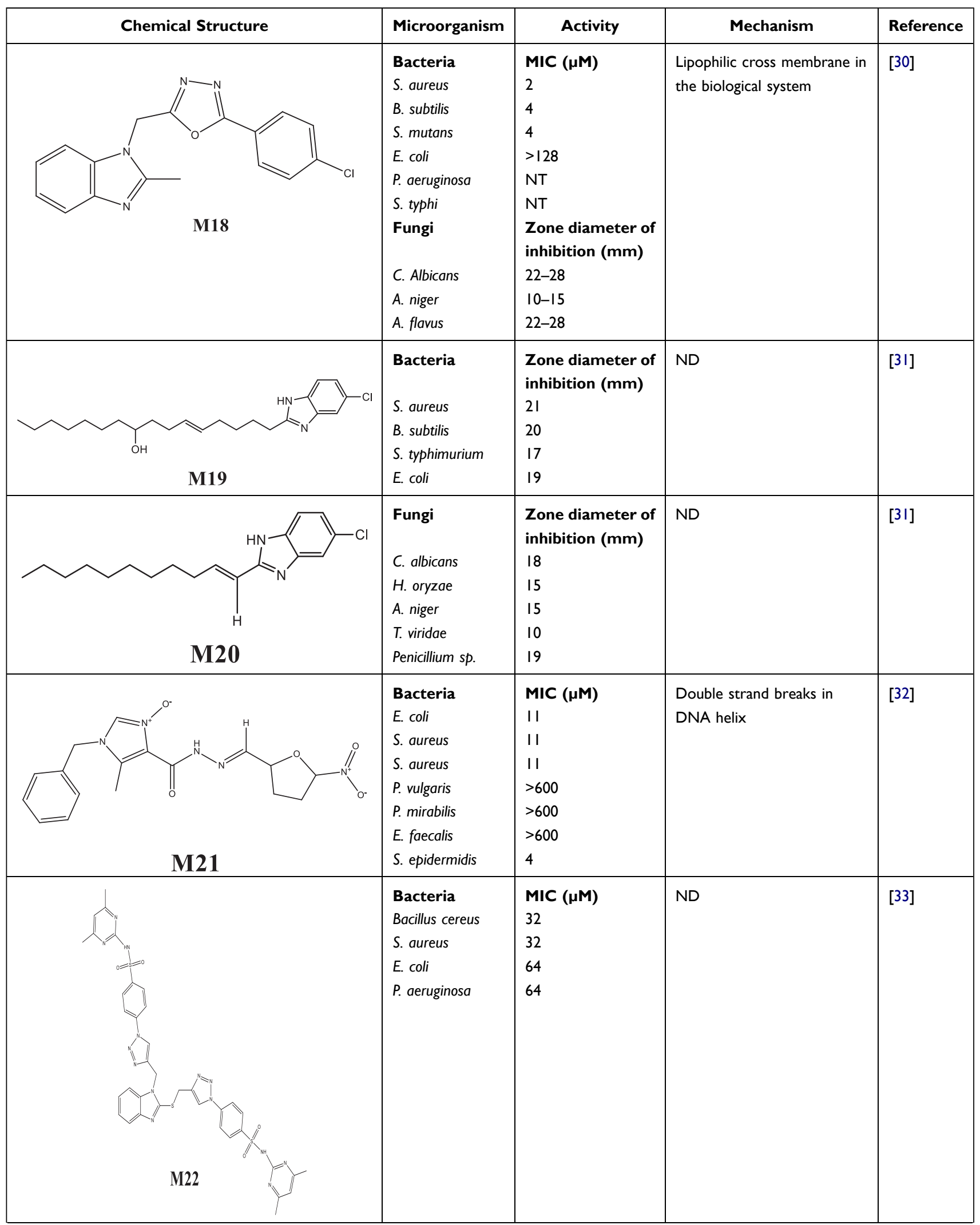

(Continued) 
Table 2 (Continued).

\begin{tabular}{|c|c|c|c|c|}
\hline Chemical Structure & Microorganism & Activity & Mechanism & Reference \\
\hline . & $\begin{array}{l}\text { Bacteria } \\
\text { E. coli } \\
\text { P. aeruginosa } \\
\text { S. aureus } \\
\text { S. pyogenes } \\
\text { ESBL } \\
\text { VRE } \\
\text { MRSA }\end{array}$ & $\begin{array}{l}\text { MIC }(\mu \mathrm{M}) \\
12.5 \\
12.5 \\
25 \\
50 \\
62.5 \\
100 \\
100\end{array}$ & ND & [34] \\
\hline & $\begin{array}{l}\text { Fungi } \\
\text { Candida albicans } \\
\text { Rhizopus oryza } \\
\text { Penicillium citrum } \\
\text { Aspergillus niger }\end{array}$ & $\begin{array}{l}\text { MIC }(\mu \mathrm{M}) \\
12.5 \text { for all fungi }\end{array}$ & ND & [35] \\
\hline & $\begin{array}{l}\text { Fungi } \\
\text { Candida albicans } \\
\text { Rhizopus oryza } \\
\text { Penicillium citrum } \\
\text { Aspergillus niger }\end{array}$ & $\begin{array}{l}\text { MIC }(\mu \mathrm{M}) \\
12.5 \text { for all fungi }\end{array}$ & ND & [35] \\
\hline & $\begin{array}{l}\text { Protozoal } \\
\text { T. b. rhodesiense } \\
\text { T. cruzi } \\
\text { L. donovani } \\
\text { P. falciparum }\end{array}$ & $\begin{array}{l}\mathrm{IC}_{50}(\mu \mathrm{M}) \\
34.43 \\
0.203 \\
15.01 \\
0.059\end{array}$ & $\begin{array}{l}\text { Target-based an assay using } \\
\text { recombinant T. cruzi CYP5I. }\end{array}$ & [36] \\
\hline M27 & $\begin{array}{l}\text { Protozoal } \\
\text { L. donovani } \\
\text { promastigotes }\end{array}$ & $\begin{array}{l}1 \mathrm{C}_{50}(\mu \mathrm{M}) \\
10\end{array}$ & Potential kinase inhibitor & [37] \\
\hline
\end{tabular}

(Continued) 
Table 2 (Continued).

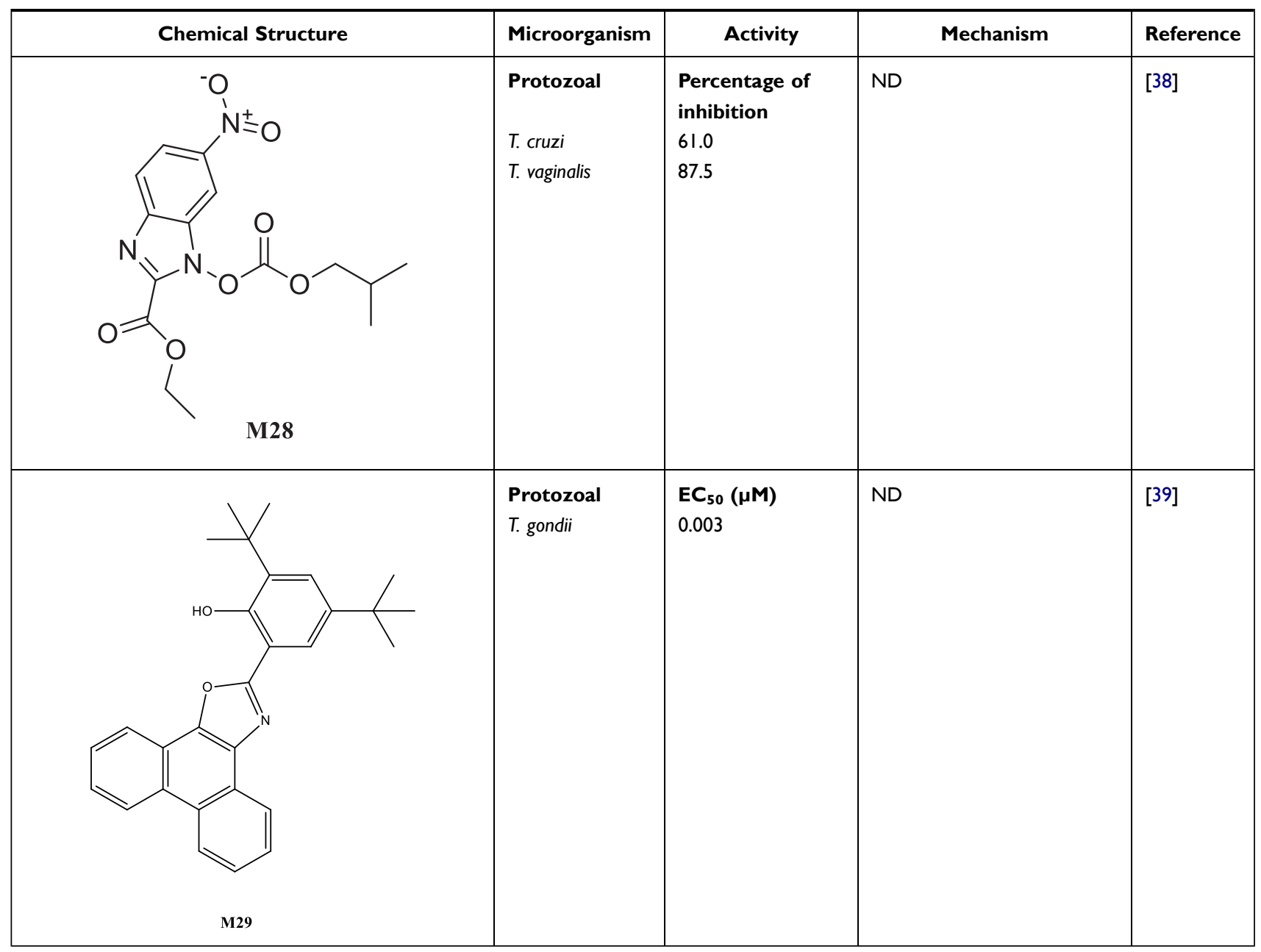

Note: The prefix M letter in the compound's number referred to Anti-Microbial activity.

Abbreviations: MIC, Minimal inhibitory concentration; $I_{50} / \mathrm{EC}_{50}$, Compound concentration required to decrease parasite viability by $50 \%$; ESBL, Extended spectrum betalactamases; VRE, Vancomycin-resistant enterococci; MRSA, Methicillin-resistance staphylococcus aureus; NT, Not tested; ND, Not determined.

reported in 2012 by Hussain et al, that investigated the activity of imidazole derivatives towards C. Albicans, R. Oryza, $P$. Citrum, and A. Niger fungal strains using Ketoconazole as a control. The minimum inhibitory concentration (MIC) was tested for M24 and M25 which was found to be $12.5 \mu \mathrm{M}$ for these two compounds among the other twenty compounds. The authors concluded that the two of the synthesized twenty imidazole derivatives, M24 and M25 were lead compounds with a strong antifungal activity that could be utilized for further development. ${ }^{35}$

\section{The Anti-Protozoal Properties of Imidazole Derivatives}

With the lack of effective treatment in addition to the resistant infections worldwide, researchers began to investigate new drugs against protozoan parasites. Herein, we reviewed the reported studies of imidazole derivatives based on their activities as anti-plasmodial, anti-leishmanial, and anti-protozoal.

According to Saccoliti et al, twenty-four Imidazolederivatives were synthesized and biologically evaluated as antiprotozoal agents, unfortunately, none of the new derivatives exhibited higher potency compared to Artemisinin (ART) as a standard drug. However, compound M26 was three times more powerful than the reference drug Chloroquine (CHQ) as well as it possessed high selectivity index $(\mathrm{SI}=253)$ that demonstrated the best anti-plasmodial activity. ${ }^{36}$

Another study done by Ramu et al has tested three imidazolidinones as a potential antileishmanial agent 
with a potential mechanism of action as a kinase inhibitor. Surprisingly, all three compounds were unable to inhibit human kinome but were potent kinome inhibitors on parasite cells. However, compound M27 had the highest $\mathrm{IC}_{50}$ of $10 \mu \mathrm{M}$. The authors concluded that compound M27 demonstrated significant antileishmanial activity via kinase inhibition. $^{37}$

Regarding the antiprotozoal activity of the (benz)imidazole derivatives, Aguirre et al examined the antiprotozoal activity in seven compounds and found that lipophilicity was essential for the potency of these compounds. At $100 \mathrm{mM}$, seven derivatives showed good activity against $T$. cruzi, while compound M28 was one of the best derivatives with a lipophilic substituent in the NO moiety. Benzimidazole derivatives showed high activity against $T$. vaginalis at 100 $\mu \mathrm{g} / \mathrm{mL}$ and $24 \mathrm{~h}$ of contact, which was sustained for three derivatives up to $48 \mathrm{~h}^{38}$

Additionally, Adeyme et al synthesized a total of twentysix new imidazole derivatives through a comparative study to Pyrimethamine, a reference drug for the treatment of Toxoplasmosis. Among the five imidazole derivatives, compound M29 demonstrated an excellent selectivity against T. gondii versus the host cells. ${ }^{39}$

\section{Anti-Inflammatory Activity of Imidazole Derivatives}

Inflammation is the predominant way of responding to a pathogen or injurious stimuli. This response includes the release of pro-inflammatory chemicals as a consequence, these chemicals increase blood vessel permeability and cause leakage of fluid into the tissues that result in pain, heat, redness, swelling, and loss of function. ${ }^{40}$ The main two types of inflammation are acute and chronic inflammation. ${ }^{41}$ Medications that are commonly used to treat inflammation are nonsteroidal anti-inflammatory drugs (NSAID) and corticosteroids. The latter is known to cause both local and systemic side effects. ${ }^{42}$ Moreover, several undesirable adverse effects could be present due to the chronic usage of nonsteroidal anti-inflammatory drugs (NSAID). ${ }^{43}$ Thus, in the pharmaceutical industry, benzimidazole is being investigated and the substituted forms of benzimidazole have also been used in various therapeutic applications. Several effective drugs currently on market, including proton pump inhibitors such as Omeprazole and Esomeprazole, and anthelmintics such as Mebendazole and Albendazole, which resulted in the optimization of benzimidazole derivatives based on their structures. ${ }^{44}$ On investigating imidazole derivatives, the current available studies reported to have promising anti-inflammatory activity based on their mechanism of action and important structureactivity relationship.

Shankar et al synthesized ten imidazole derivatives and screened their anti-inflammatory activities using cyclooxygenase-1 (COX-1) and cyclooxygenase-2 (COX-2) enzymes in vitro. Compound I30 demonstrated potent COX-2 inhibition with a percentage of 78.68 that is greater than the standard drug Ibuprofen (COX-2 inhibition percentage of 29.67). Additionally, in-vitro results were welltranslated to the in-vivo environment in which compound I30 showed good anti-inflammatory activity against COX2 enzyme with an inhibition percentage of 54.314 compared to Ibuprofen (52.986). ${ }^{45}$

Using in vitro Ellman's method-based assay investigated by Bukhari et al, several anti-inflammatory agents were studied as potential inhibitors of COXs, phospholipase A2, lipoxygenase, TNF- $\alpha$, and IL-6 using Indomethacin as a standard. Between thirty-five compounds, compound I31 was the most potent compound as an inhibitor of COX-1, COX-2, 5-LOX, and SPLA2-V with $\mathrm{IC}_{50}$ of $0.98,11.56,09.51$, and 5.21, respectively. ${ }^{50}$ Furthermore, Katikireddy et al investigated five compounds for their anti-inflammatory activity in vivo based on their potential antioxidant activity. The selected compounds showed comparable anti-inflammatory activity, decreased paw volume, relative to the standard drug Indomethacin. Moreover, compound I32 was the most effective anti-inflammatory agent with a percent inhibition of 90.30 at 6 hours. Compound I32 had a dichloride substitution at ortho and para positions which are responsible for the potent anti-inflammatory activity. Additional docking studies revealed that compound $\mathrm{I} 32$ binds to the active site of cyclooxygenase-2 (COX-2) confirming the in-vitro results. $^{47}$

Nascimento et al have synthesized eight novel imidazole derivatives to be tested as a potential antiinflammatory agent in vitro. Compound I33 was the most potent inhibitor of nuclear factor kappa B (NF- $\mathrm{B})$ transcription factor transmigration. Furthermore, compound I33 effectively reduced the pro-inflammatory mediators in addition to inhibition of nitric oxide release in $\mathbf{J 7 7 4}$ macrophage. The author concluded that compound I33 demonstrated similar efficacy in both in vitro and in vivo studies suggesting it could serve as a potential antiinflammatory agent. ${ }^{49}$ 
In this regard, Rocha et al have investigated two imidazole alkaloids to study the anti-inflammatory activity on human neutrophils with Indomethacin as a reference agent. The results of this study showed that I34 has good activity against neutrophils degranulation, reactive oxygen species (ROS), and IL-6 production. These results were confirmed using in vivo model that decreased inflammatory hypernociception and myeloperoxidase (MPO) release in mice. ${ }^{48}$

Moreover, some authors reported SAR studies based on applying a medicinal chemistry approach from available anti-inflammatory drugs. For example, Husain et al believed that safe and effective NSAIDs would still be needed. Therefore, the author investigated Di- and trisubstituted imidazole derivatives using carrageenaninduced rat paw edema. The study results showed that six compounds displayed remarkable anti-inflammatory activity from 49.58 to $58.02 \%$ edema inhibition with minimal GI discomfort and severity index from 0.17 to 0.34 in vivo. Husain et al noted that compounds I35 and I36 are biologically active lead compounds with a promising antiinflammatory activity that could be utilized as a novel antiinflammatory candidate. ${ }^{35}$

Furthermore, another study investigated in-vivo analgesic and anti-inflammatory activities of eleven synthesized compounds. The results showed that compound I37 demonstrated the strongest anti-inflammatory activity at $100 \mathrm{mg} / \mathrm{kg}$ compared to Nimesulide. However, the other nine compounds demonstrated a moderate antiinflammatory activity. The initial in-vivo studies of these compounds showed that the chlorine group in meta position on the aniline ring improved both analgesic and antiinflammatory properties, which could serve as new models for synthesizing more powerful immunomodulatory therapies. ${ }^{44}$

An additional study in which authors evaluated twentythree compounds against human erythrocytes. Among the synthesized compounds, compound I38 demonstrated excellent activity with an $\mathrm{IC}_{50}$ of $44 \mu \mathrm{M}$ that is higher than standard Aspirin $\left(\mathrm{IC}_{50}\right.$ of $\left.200 \mu \mathrm{M}\right)$ and Indomethacin $\left(\mathrm{IC}_{50}\right.$ of $112 \mu \mathrm{M})$. Furthermore, as the number of electrons withdrawing moiety in the benzene ring increases the antiinflammatory activity also increases. The authors concluded that compounds $\mathrm{I} 38$ with two $\mathrm{NO}_{2}$ substitutions on the benzene ring exhibited an excellent anti-inflammatory activity compared to aspirin and indomethacin. ${ }^{46}$

Moreover, Gaba investigated the anti-inflammatory activity of nine imidazole compounds using a carrageenaninduced rat paw edema method, and results demonstrated that three compounds showed anti-inflammatory activity ranging from 20.90 to $46.27 \%$ of inhibition. ${ }^{51}$ It is anticipated that the three electron-donating substituents in the three compounds showed a highly significant reduction in edema, the highest reduction was in compound I39 with $46.27 \%$ compared to the standard drug Indomethacin with $47.76 \%$. The authors stated that compound 139 could be utilized as a lead compound for the discovery of novel anti-inflammatory drugs. All the anti-inflammatory studies are summarized in Table 3.

\section{Pharmacokinetics ADME Properties of Selected Imidazole Derivatives}

The ADME analysis was calculated using the SwissADME webserver. To determine whether the imidazole derivatives fulfill the drug-likeness properties, we have selected the most potent imidazole derivatives that demonstrated high potency as anti-cancer, anti-microbial, and anti-inflammatory effects from the above-discussed studies. The ADME properties are present in Tables 5Tables 4-6 and the SMILE for each compound are summarized in Table 1S.

\section{Molecular Weight (MW)}

Considering Lipinski's rule limit of molecular weight (MW) of 500, it is apparent that all imidazole compounds were within the recommended range which improves their chances to be absorbed orally in the gastrointestinal tract, except for compound $\mathrm{C} 2, \mathrm{C} 15, \mathrm{C} 16, \mathrm{M} 22$, and M23 with an MW of 739.04, 607.65, 586.66, 834.95, and 521.61g/ mol, respectively. ${ }^{52}$ The compounds with high MW do not pass through the cell membrane as readily as small MW, not only that but also low MW molecules are likely to be absorbed, diffused, transported across the cell membrane, and be more soluble compared to high $\mathrm{MW}^{53,54}$ Importantly, compound I39 showed great promise as a lead compound to develop a novel class of orally active anti-inflammatory agents with fewer GI side effects. ${ }^{51}$

\section{Lipophilicity (Log P) and Gastrointestinal (GI) Absorption}

In drug discovery and design, lipophilicity, which is measured by the octanol/water partition coefficient, is an important physicochemical property that enhances compound GI absorption, safety, and efficacy. ${ }^{55}$ All the imidazole derivatives demonstrated promising results in lipophilicity as leading compounds to generate a novel 
Table 3 The Anti-Inflammatory Activities of Imidazole Derivatives in Multiple in vitro/ In vivo Models

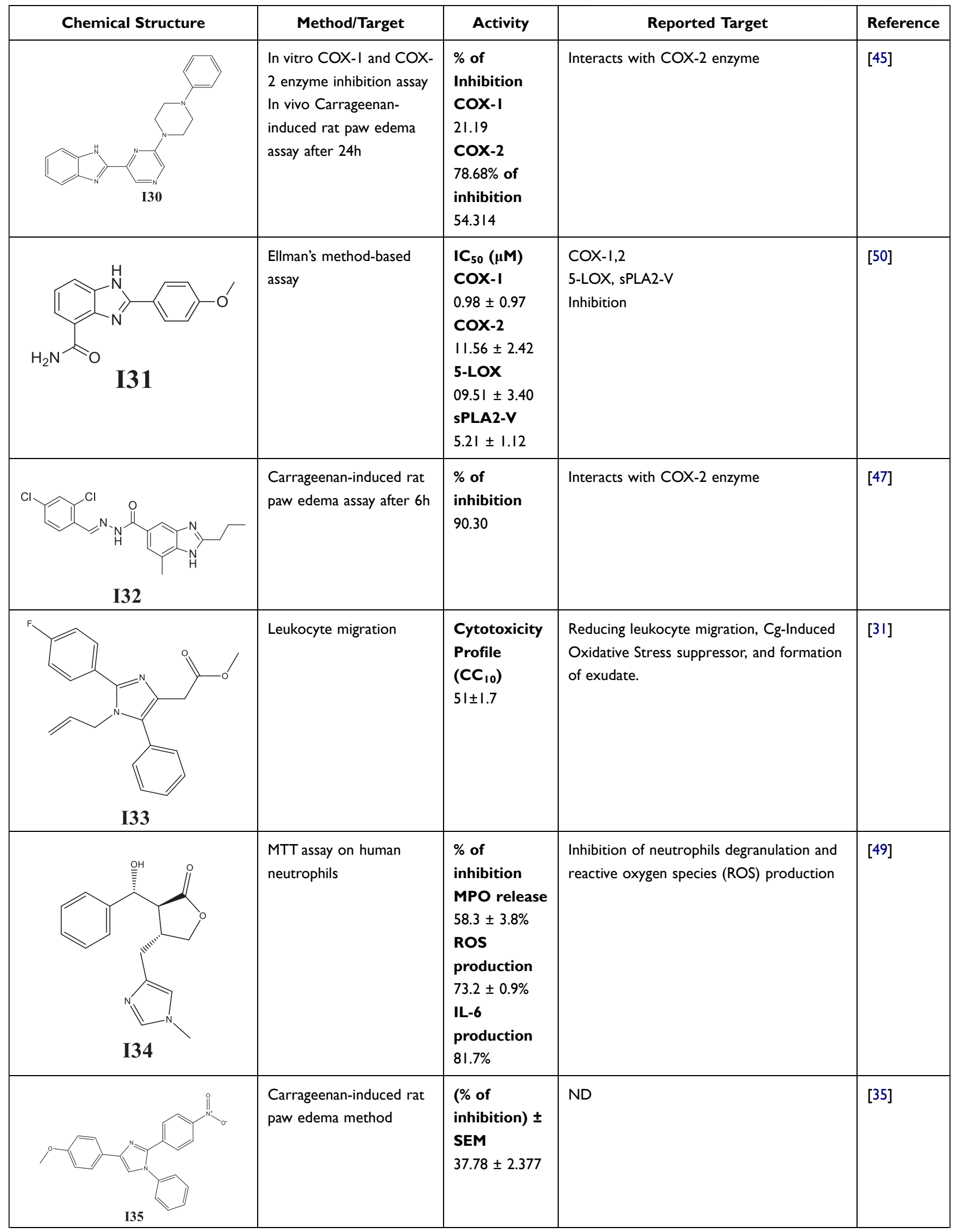


Table 3 (Continued).

\begin{tabular}{|c|c|c|c|c|}
\hline Chemical Structure & Method/Target & Activity & Reported Target & Reference \\
\hline & $\begin{array}{l}\text { Carrageenan-induced rat } \\
\text { paw edema method }\end{array}$ & $\begin{array}{l}\text { (\% of } \\
\text { inhibition }) \pm \\
\text { SEM } \\
24.67 \pm 1.213\end{array}$ & ND & [35] \\
\hline & $\begin{array}{l}\text { Carrageenan-induced rat } \\
\text { paw edema method after } \\
\text { 3h }\end{array}$ & $\begin{array}{l}\% \text { of oedema } \\
\text { inhibition } \\
44.4\end{array}$ & ND & [44] \\
\hline & Human erythrocyte & $\begin{array}{l}1 C_{50}(\mu \mathrm{M}) \\
44 \pm 0.17\end{array}$ & ND & [46] \\
\hline & $\begin{array}{l}\text { Carrageenan-induced rat } \\
\text { paw edema at } 3 \mathrm{~h}\end{array}$ & $\begin{array}{l}\% \text { of } \\
\text { inhibition } \\
53.73\end{array}$ & ND & [5I] \\
\hline I39 & & & & \\
\hline
\end{tabular}

Notes: The prefix "l” letter in the compound's number referred to Anti-inflammatory activity. The cytotoxic concentration that killed I0\% of the cells (CC $\left.{ }_{10}\right)$ was calculated through nonlinear regression analysis of the logarithm of concentration in the function of the normalized response (percentage of cell viability). Results are expressed as mean \pm E.P.M.

Abbreviations: $I C_{50}$, The concentration that inhibits enzyme activity by $50 \%$; ND, Not determined.

class of orally active agents in the recommended range of $-2.0-6.5$ except for compounds C2, C10, C13, M19 M22, M26, and M29. ${ }^{55}$ Moreover, all the compounds showed high gastrointestinal (GI) absorption except for compounds C2, C3, C14-16, M19, M22, M23, M26, M29, and I34 that could be due to their high MW.

\section{Blood-Brain Barrier (BBB) Permeability}

Chemical structures can be modified to increase or decrease BBB permeability by structural design. Since lipophilicity is a key determinant in BBB permeability, it is useful to use this property in brain tumors. All the imidazole compounds cannot cross BBB except for compounds $\mathrm{C} 1, \mathrm{C} 7-9, \mathrm{C} 11, \mathrm{C} 17, \mathrm{M} 18, \mathrm{M} 25, \mathrm{I} 31-33$, and I36-37 due to the balanced lipophilicity/solubility properties that could greatly help to treat some central nervous system diseases which require BBB crossing ability. ${ }^{56,57}$

\section{Solubility (Log S)}

Log $\mathrm{S}$ which predicts the aqueous solubility, with a recommended range of -6.5 to 0.5 , of a compound has a direct effect on its absorption. ${ }^{56}$ Therefore, low water solubility is associated with poor GI absorption, and thus the general goal is to avoid insoluble compounds such as C2, C3, C10, C15, C16, M22, M26, and M2. The rest of the imidazole derivatives displayed high to moderate water solubility based on the ADME predictions. ${ }^{56}$ 
Table 4 The Pharmacokinetics ADME Properties of Selected Imidazole Derivatives as Anti-Cancer Agents

\begin{tabular}{|c|c|c|c|c|c|c|c|c|}
\hline $\begin{array}{l}\text { Compounds } \\
\text { Codes }\end{array}$ & $\begin{array}{l}\text { Molecular } \\
\text { Weight }\end{array}$ & $\begin{array}{c}\text { HB } \\
\text { Donor }\end{array}$ & $\begin{array}{c}\text { HB } \\
\text { Acceptor }\end{array}$ & $\begin{array}{l}\text { Log Po/w } \\
\text { (WLOGP) }\end{array}$ & $\begin{array}{c}\log S \text { (SILICO } \\
\text { S-IT) }\end{array}$ & $\begin{array}{c}\text { BBB } \\
\text { Permeant }\end{array}$ & $\begin{array}{c}\text { GI } \\
\text { Absorption }\end{array}$ & $\begin{array}{l}\text { Rule of Five } \\
\text { (ROF) }\end{array}$ \\
\hline \multicolumn{9}{|c|}{ Imidazole Derivatives as Anti-Cancer } \\
\hline $\mathrm{Cl}$ & $360.84 \mathrm{~g} / \mathrm{mol}$ & 2 & 3 & 4.18 & $\begin{array}{c}-6.12 \\
\text { Poorly soluble }\end{array}$ & Yes & High & Yes; 0 violation \\
\hline C2 & $739.04 \mathrm{~g} / \mathrm{mol}$ & 2 & 5 & 7.36 & $\begin{array}{l}-12.75 \\
\text { Insoluble }\end{array}$ & No & Low & $\begin{array}{c}\text { Yes; I violation: } \\
M W>500\end{array}$ \\
\hline $\mathrm{C} 3$ & $388.43 \mathrm{~g} / \mathrm{mol}$ & 4 & 5 & 2.28 & $\begin{array}{c}-6.84 \\
\text { Poorly soluble }\end{array}$ & No & High & Yes; 0 violation \\
\hline C4 & $372.93 \mathrm{~g} / \mathrm{mol}$ & 1 & 2 & 6.39 & $\begin{array}{c}-8.42 \\
\text { Poorly soluble }\end{array}$ & No & High & Yes; 0 violation \\
\hline C5 & $269.17 \mathrm{~g} / \mathrm{mol}$ & 0 & 1 & 4.77 & $\begin{array}{c}-4.86 \\
\text { Moderately } \\
\text { soluble }\end{array}$ & Yes & High & Yes; 0 violation \\
\hline C6 & $366.60 \mathrm{~g} / \mathrm{mol}$ & 2 & 3 & 3.23 & $\begin{array}{c}-6.46 \\
\text { Poorly soluble }\end{array}$ & Yes & High & Yes; 0 violation \\
\hline C7 & $447.28 \mathrm{~g} / \mathrm{mol}$ & 0 & 5 & 3.75 & $\begin{array}{c}-5.97 \\
\text { Moderately } \\
\text { soluble }\end{array}$ & Yes & High & Yes; 0 violation \\
\hline $\mathrm{C} 8$ & $408.27 \mathrm{~g} / \mathrm{mol}$ & 0 & 5 & 4.32 & $\begin{array}{c}-6.59 \\
\text { Poorly soluble }\end{array}$ & No & High & Yes; 0 violation \\
\hline C9 & $294.31 \mathrm{~g} / \mathrm{mol}$ & 4 & 6 & -1.48 & $\begin{array}{l}-2.02 \\
\text { Soluble }\end{array}$ & No & Low & Yes; 0 violation \\
\hline $\mathrm{ClO}$ & $490.60 \mathrm{~g} / \mathrm{mol}$ & 0 & 2 & 7.50 & $\begin{array}{l}-12.48 \\
\text { Insoluble }\end{array}$ & No & Low & Yes; 0 violation \\
\hline $\mathrm{Cll}$ & $365.22 \mathrm{~g} / \mathrm{mol}$ & 1 & 3 & 5.63 & $\begin{array}{c}-9.22 \\
\text { Poorly soluble }\end{array}$ & Yes & High & Yes; 0 violation \\
\hline $\mathrm{Cl} 2$ & $460.53 \mathrm{~g} / \mathrm{mol}$ & 2 & 6 & 2.44 & $\begin{array}{c}-7.50 \\
\text { Poorly soluble }\end{array}$ & No & High & Yes; 0 violation \\
\hline $\mathrm{Cl} 3$ & $607.65 \mathrm{~g} / \mathrm{mol}$ & 3 & 9 & 8.66 & $\begin{array}{l}-12.88 \\
\text { insoluble }\end{array}$ & No & Low & $\begin{array}{c}\text { Yes; I violation: } \\
\quad M W>500\end{array}$ \\
\hline $\mathrm{Cl} 4$ & $586.66 \mathrm{~g} / \mathrm{mol}$ & 2 & 6 & 5.87 & $\begin{array}{c}-10.64 \\
\text { insoluble }\end{array}$ & No & Low & $\begin{array}{c}\text { No; I violation: } \\
\quad M W>500\end{array}$ \\
\hline $\mathrm{Cl} 5$ & $437.66 \mathrm{~g} / \mathrm{mol}$ & 2 & 2 & 7.84 & $\begin{array}{l}-10.19 \\
\text { Insoluble }\end{array}$ & No & Low & Yes; 0 violation \\
\hline $\mathrm{Cl} 6$ & $390.39 \mathrm{~g} / \mathrm{mol}$ & 1 & 5 & 2.50 & $\begin{array}{c}-5.09 \\
\text { Moderately } \\
\text { soluble }\end{array}$ & No & High & Yes; 0 violation \\
\hline $\mathrm{Cl}$ & $365.81 \mathrm{~g} / \mathrm{mol}$ & 1 & 2 & 3.13 & $\begin{array}{c}-6.33 \\
\text { Poorly soluble }\end{array}$ & Yes & High & Yes; 0 violation \\
\hline
\end{tabular}

\section{Hydrogen Bond Donor and Acceptor (HBD/HBA)}

The hydrogen bond donors (HBD) increase acidity while hydrogen bond acceptor (HBA) increases basicity. Using
ADME predictions, all compounds obeyed Lipinski's rule regarding the number of hydrogen bond donors from 0 to 6 and hydrogen bond acceptors from 2 to 10 except for compounds M22 which has 13 hydrogen bond acceptors. ${ }^{54,58,59}$ 
Table 5 The Pharmacokinetics ADME Properties of Selected Imidazole Derivatives as Anti-Microbial Agents

\begin{tabular}{|c|c|c|c|c|c|c|c|c|}
\hline $\begin{array}{l}\text { Compounds } \\
\text { Codes }\end{array}$ & $\begin{array}{l}\text { Molecular } \\
\text { Weight }\end{array}$ & $\begin{array}{c}\text { HB } \\
\text { Donor }\end{array}$ & $\begin{array}{c}\text { HB } \\
\text { Acceptor }\end{array}$ & $\begin{array}{l}\text { Log Po/w } \\
\text { (WLOGP) }\end{array}$ & $\begin{array}{c}\text { Log } \\
\text { S (SILICO } \\
\text { S-IT) }\end{array}$ & $\begin{array}{c}\text { BBB } \\
\text { Permeant }\end{array}$ & $\begin{array}{c}\text { GI } \\
\text { Absorption }\end{array}$ & Rule of Five (ROF) \\
\hline \multicolumn{9}{|c|}{ Imidazole Derivatives as Anti-microbial } \\
\hline MI8 & $\begin{array}{c}324.76 \mathrm{~g} / \\
\mathrm{mol}\end{array}$ & 0 & 4 & 4.10 & $\begin{array}{l}-6.97 \\
\text { Poorly } \\
\text { soluble }\end{array}$ & Yes & High & Yes; 0 violation \\
\hline MI9 & $\begin{array}{c}390.99 \mathrm{~g} / \\
\mathrm{mol}\end{array}$ & 2 & 2 & 6.99 & $\begin{array}{l}-8.26 \\
\text { Poorly } \\
\text { soluble }\end{array}$ & No & Low & Yes; 0 violation \\
\hline M20 & $\begin{array}{c}304.86 \mathrm{~g} / \\
\mathrm{mol}\end{array}$ & I & I & 6.26 & $\begin{array}{c}-7.23 \text { Poorly } \\
\text { soluble }\end{array}$ & No & High & Yes; 0 violation \\
\hline M2I & $\begin{array}{c}373.36 \mathrm{~g} / \\
\mathrm{mol}\end{array}$ & 1 & 6 & 0.98 & $\begin{array}{c}-2.3 \\
\text { Soluble }\end{array}$ & No & High & Yes; 0 violation \\
\hline M22 & $\begin{array}{c}834.95 \mathrm{~g} / \\
\mathrm{mol}\end{array}$ & 2 & 13 & 6.58 & $\begin{array}{c}-12.74 \\
\text { Insoluble }\end{array}$ & No & Low & $\begin{array}{c}\text { No; } 2 \text { violations: } \\
M W>500, \text { NorO }>10\end{array}$ \\
\hline M23 & $\begin{array}{c}521.61 \mathrm{~g} / \\
\mathrm{mol}\end{array}$ & 1 & 6 & 5.21 & $\begin{array}{l}-8.08 \\
\text { Poorly } \\
\text { soluble }\end{array}$ & No & Low & $\begin{array}{l}\text { Yes; I violation: } \\
\qquad M W>500\end{array}$ \\
\hline M24 & $\begin{array}{c}371.39 \mathrm{~g} / \\
\mathrm{mol}\end{array}$ & 0 & 4 & 5.12 & $\begin{array}{l}-7.41 \\
\text { Poorly } \\
\text { soluble }\end{array}$ & No & High & Yes; 0 violation \\
\hline M25 & $\begin{array}{c}356.42 \mathrm{~g} / \\
\mathrm{mol}\end{array}$ & 0 & 3 & 5.22 & $\begin{array}{l}-8.17 \\
\text { Poorly } \\
\text { soluble }\end{array}$ & Yes & High & Yes; 0 violation \\
\hline M26 & $\begin{array}{c}444.36 \mathrm{~g} / \\
\mathrm{mol}\end{array}$ & 1 & I & 7.49 & $\begin{array}{c}-10.85 \\
\text { Insoluble }\end{array}$ & No & Low & Yes; 0 violation \\
\hline M27 & $\begin{array}{c}189.17 \mathrm{~g} / \\
\mathrm{mol}\end{array}$ & 2 & 3 & $-0.6 \mathrm{I}$ & $\begin{array}{l}-2.77 \\
\text { Soluble }\end{array}$ & No & High & Yes; 0 violation \\
\hline M28 & $\begin{array}{c}351.31 \mathrm{~g} / \\
\mathrm{mol}\end{array}$ & 0 & 8 & 2.34 & $\begin{array}{l}-2.56 \\
\text { Soluble }\end{array}$ & No & High & Yes; 0 violation \\
\hline M29 & $\begin{array}{c}423.55 \mathrm{~g} / \\
\mathrm{mol}\end{array}$ & I & 3 & 8.10 & $\begin{array}{c}-10.53 \\
\text { Insoluble }\end{array}$ & No & Low & Yes; 0 violation \\
\hline
\end{tabular}

\section{Target Predictions of Selected Imidazole Derivatives}

The bioactivity scores of selected imidazole derivatives were calculated using Molinspiration virtual screening webserver. ${ }^{60}$ In Table 7, the larger the bioactivity score correlates with the higher probability that a specific molecule will be active at that target. ${ }^{2}$ Results showed that compound $\mathrm{C} 4$ may work by five different mechanisms that give a better chance to be a promising novel anticancer agent. Interestingly, the computational bioavailability scores correlated well with the previously reported studies for some of the proposed targets. For example, $\mathrm{C} 4$ was reported to act through inhibition of focal adhesion kinase (FAK) and computational results demonstrated that $\mathrm{C} 4$ exhibited a high bioactivity score as a kinase inhibitor. ${ }^{12}$ In similar manner, the anti-cancer mechanisms of compounds $\mathrm{C} 1, \mathrm{C} 12, \mathrm{C} 13$, and $\mathrm{C} 15$ were reported to inhibit Topoisomerase IIR, aurora kinase, tubulin polymerization, and $\mathrm{BRAF}^{\mathrm{V} 600 \mathrm{E}}$ kinase, respectively. These 
Table 6 The Pharmacokinetics ADME Properties of Selected Imidazole Derivatives as Anti-Inflammatory Agents

\begin{tabular}{|c|c|c|c|c|c|c|c|c|}
\hline $\begin{array}{l}\text { Compounds } \\
\text { Codes }\end{array}$ & $\begin{array}{l}\text { Molecular } \\
\text { Weight }\end{array}$ & $\begin{array}{c}\text { HB } \\
\text { Donor }\end{array}$ & $\begin{array}{c}\text { HB } \\
\text { Acceptor }\end{array}$ & $\begin{array}{l}\text { Log Po/w } \\
\text { (WLOGP) }\end{array}$ & $\begin{array}{c}\text { Log } \\
\text { S (SILICO } \\
\text { S-IT) }\end{array}$ & $\begin{array}{c}\text { BBB } \\
\text { Permeant }\end{array}$ & $\begin{array}{c}\text { GI } \\
\text { Absorption }\end{array}$ & $\begin{array}{l}\text { Rule of Five } \\
\text { (ROF) }\end{array}$ \\
\hline \multicolumn{9}{|c|}{ Imidazole Derivatives as Anti-inflammatory } \\
\hline 130 & $356.42 \mathrm{~g} / \mathrm{mol}$ & $\mathrm{I}$ & 3 & 2.58 & $\begin{array}{c}-6.94 \\
\text { Poorly soluble }\end{array}$ & Yes & High & Yes; 0 violation \\
\hline |3 | & $267.28 \mathrm{~g} / \mathrm{mol}$ & 2 & 3 & 2.34 & $\begin{array}{l}-5.15 \\
\text { Moderately } \\
\text { soluble }\end{array}$ & No & High & Yes; 0 violation \\
\hline 132 & $389.28 \mathrm{~g} / \mathrm{mol}$ & 2 & 3 & 4.89 & $\begin{array}{l}-8.27 \\
\text { Poorly soluble }\end{array}$ & No & High & Yes; 0 violation \\
\hline 133 & $350.39 \mathrm{~g} / \mathrm{mol}$ & 0 & 4 & 4.68 & $\begin{array}{c}-7.02 \\
\text { Poorly soluble }\end{array}$ & Yes & High & Yes; 0 violation \\
\hline 134 & $286.33 \mathrm{~g} / \mathrm{mol}$ & $\mathrm{I}$ & 4 & 1.16 & $\begin{array}{l}-3.46 \\
\text { Soluble }\end{array}$ & Yes & High & Yes; 0 violation \\
\hline 135 & $371.39 \mathrm{~g} / \mathrm{mol}$ & 0 & 4 & 5.12 & $\begin{array}{c}-7.4 \mathrm{I} \\
\text { Poorly soluble }\end{array}$ & No & High & Yes; 0 violation \\
\hline 136 & $342.39 \mathrm{~g} / \mathrm{mol}$ & 1 & 3 & 4.92 & $\begin{array}{c}-7.48 \\
\text { Poorly soluble }\end{array}$ & Yes & High & Yes; 0 violation \\
\hline 137 & $257.72 \mathrm{~g} / \mathrm{mol}$ & 2 & I & 3.49 & $\begin{array}{l}-6.50 \\
\text { Poorly soluble }\end{array}$ & Yes & High & Yes; 0 violation \\
\hline 138 & $404.38 \mathrm{~g} / \mathrm{mol}$ & 3 & 8 & 2.06 & $\begin{array}{c}-3.97 \\
\text { Moderately } \\
\text { soluble }\end{array}$ & No & Low & $\begin{array}{l}\text { Yes; I violation: } \\
\text { NorO }>10\end{array}$ \\
\hline 139 & $407.49 \mathrm{~g} / \mathrm{mol}$ & I & 4 & 4.94 & $\begin{array}{l}-7.93 \\
\text { Poorly soluble }\end{array}$ & No & High & Yes; 0 violation \\
\hline
\end{tabular}

four compounds exhibited high bioactivity scores as kinase inhibitors that provide additional confirmation to the reported studies. ${ }^{14,20,21}$ Moreover, compound $\mathrm{C} 10$ could act via four mechanisms one of which is GPCR which is consistent with the previously reported study about $\mathrm{C} 10$ and its action through dimerization of estrogen receptor. ${ }^{18}$ Compound $\mathrm{C} 11$ was suggested to stabilize DNA c-MYC G-quadruplex by modulating ion-channel and this was confirmed with our target prediction score of $0.30 .{ }^{19}$ However, compound $\mathrm{C} 14$ was reported to work on GSK-3 $\beta$ which is one of the kinase enzymes but our target prediction score of -0.34 did not correlate with AlBlewi et al study. ${ }^{24}$ All the proposed mechanisms for imidazole derivatives are summarized in Figure 1.

The results shown in Table 8, indicate that compound M21 was the most promising compound as a GPCR ligand and kinase inhibitor. Moreover, enzyme inhibition tends to be a crucial factor for selecting lead candidates for T. species therapy. Moreover, M27 was proposed to be a kinase inhibitor, however, the computational results did not suggest that with a score of $-0.30 .{ }^{37}$ Furthermore, compound M26 exhibited the highest bioactivity against all the investigated targets, one of which is enzymes (a score of 0.6) that is consistent with Saccoliti et al study which mentioned the compound works by inhibiting the CYP51 enzyme as a possible mechanism of action. $^{36}$

The findings shown in Table 9, demonstrated that some anti-inflammatory mechanisms of imidazole derivatives could be due to the interactions with GPCRs, nuclear receptors, ion channels, proteases, kinases, and enzymes. According to the bioactivity scores, the most promising compounds were found to be I30, I31, I33, and I34 with scores of $0.24,0.32,0.21$, and 0.72 , respectively, as an enzyme inhibitor suggesting COX enzyme may be involved in mediating this anti-inflammatory effect that 
Table 7 The Target Predictions of Imidazole Derivatives as Anti-Cancer

\begin{tabular}{|c|c|c|c|c|c|c|c|c|}
\hline $\begin{array}{l}\text { Compounds } \\
\text { Codes }\end{array}$ & $\begin{array}{l}\text { GPCR } \\
\text { Ligand }\end{array}$ & $\begin{array}{l}\text { Ion Channel } \\
\text { Modulator }\end{array}$ & $\begin{array}{l}\text { Kinase } \\
\text { Inhibitor }\end{array}$ & $\begin{array}{l}\text { Nuclear } \\
\text { Receptor } \\
\text { Ligand }\end{array}$ & $\begin{array}{l}\text { Protease } \\
\text { Inhibitor }\end{array}$ & $\begin{array}{l}\text { Enzyme } \\
\text { Inhibitor }\end{array}$ & Reported Target & Reference \\
\hline \multicolumn{9}{|c|}{ Imidazole Derivatives as Anti-Cancer } \\
\hline $\mathrm{Cl}$ & -0.10 & -0.20 & 0.08 & -0.41 & -0.57 & -0.33 & $\begin{array}{l}\text { Topoisomerase IIR } \\
\text { catalytic inhibitors. }\end{array}$ & [9] \\
\hline $\mathrm{C} 2$ & -0.89 & -2.07 & -1.81 & -1.61 & -0.81 & -1.39 & ND & {$[10]$} \\
\hline $\mathrm{C} 3$ & 0.23 & 0.16 & 0.61 & -0.87 & 0.21 & 0.12 & $\begin{array}{l}\text { Focal Adhesion Kinase } \\
\text { (FAK) inhibition. }\end{array}$ & {$[12]$} \\
\hline $\mathrm{C} 4$ & 0.53 & 0.34 & 0.28 & -0.05 & 0.10 & 0.41 & ND & [14] \\
\hline C5 & -0.09 & -0.14 & -0.12 & -0.62 & -0.62 & -0.02 & $\begin{array}{l}\text { Cyclin-dependent kinase } \\
6(\mathrm{CDK} 6) \text { inhibition }\end{array}$ & {$[15]$} \\
\hline $\mathrm{C} 6$ & -0.20 & -0.23 & 0.41 & -0.59 & -0.48 & 0.25 & ND & [16] \\
\hline $\mathrm{C7}$ & -0.13 & -0.64 & 0.03 & -0.46 & -0.52 & -0.18 & ND & {$[17]$} \\
\hline $\mathrm{C} 8$ & -0.16 & -0.27 & 0.13 & -0.48 & -0.33 & 0.06 & $\begin{array}{l}\text { Inhibit tubulin } \\
\text { polymerization }\end{array}$ & {$[21]$} \\
\hline $\mathrm{C9}$ & -0.35 & -1.07 & -0.69 & -1.19 & -0.48 & -0.14 & ND & [22] \\
\hline $\mathrm{ClO}$ & 0.13 & 0.11 & 0.28 & -0.03 & -0.09 & 0.09 & $\begin{array}{c}\text { ND } \\
\text { Possibly due to } \\
\text { dimerized estrogen } \\
\text { receptor }\end{array}$ & [18] \\
\hline $\mathrm{CII}$ & 0.32 & 0.30 & 0.51 & -0.19 & -0.24 & 0.31 & $\begin{array}{l}\text { c-MYC G-quadruplex } \\
\text { DNA stabilizers }\end{array}$ & [19] \\
\hline $\mathrm{Cl} 2$ & 0.18 & -0.16 & 0.37 & -0.45 & -0.11 & 0.04 & Aurora kinase inhibition & [20] \\
\hline $\mathrm{Cl} 3$ & 0.12 & -0.47 & 0.13 & -0.30 & -0.07 & -0.07 & Inhibit $\mathrm{BRAF}^{\mathrm{V} 600 \mathrm{E}}$ kinase & [23] \\
\hline $\mathrm{Cl} 4$ & -0.28 & -0.85 & -0.34 & -0.62 & -0.34 & -0.20 & Inhibit GSK-3 $\beta$ & [24] \\
\hline $\mathrm{Cl} 5$ & 0.35 & 0.16 & 0.20 & -0.04 & 0.20 & 0.29 & ND & {$[\mathrm{II}]$} \\
\hline $\mathrm{Cl} 6$ & -0.86 & -1.08 & -1.15 & -1.02 & -1.16 & -0.60 & ND & {$[13]$} \\
\hline $\mathrm{Cl}$ & 0.12 & 0.04 & -0.15 & -0.38 & 0.03 & 0.00 & ND & [25] \\
\hline
\end{tabular}

correlated well with Shankar et al, Bukhari et al, Nascimento et al and Rocha et al studies. ${ }^{45,48-50}$ On the contrary, Katikireddy et al believed that compound $\mathrm{I} 32$ works by inhibiting the COX-2 enzyme, however, the target prediction did not show a promising bioactivity score at this target suggesting computational studies should not be used solely for target predictions. ${ }^{47}$

\section{Future Direction}

The current review illustrates that imidazole derivatives have promising pharmacological effects particularly as anticancer, anti-microbial, and anti-inflammatory with a great potential for treating various human diseases. Computational studies were performed to encapsulate some of the important parameters of lead optimization such as ADME and target predictions for the highly potent candidates. Our results showed that several imidazole derivatives demonstrated an acceptable pharmacokinetic profile with promising bioavailability scores that correlated well with reported targets. Moreover, several considerations could be taken into account for the development of imidazole derivatives such as the 


\section{Proposed Mechanisms for Imidazole Derivatives}

(1) Anti-Cancer:

Focal

Adhesion

Kinase

Inhibition<smiles>[CH]1[CH]CC1</smiles>

Cyclin Dependent Kinase Inhibition

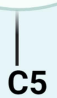

\section{Induction of Apoptosis}

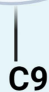

Angiogenesis

Supression

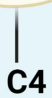

Topoisomerase

II Inhibition

Tubulin

Polymerization

inhibition
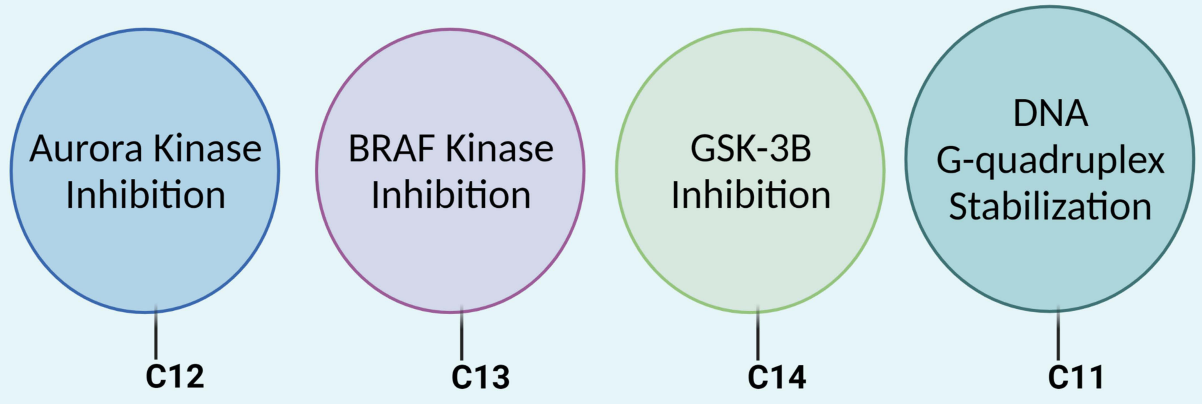

(2) Anti-Microbial:
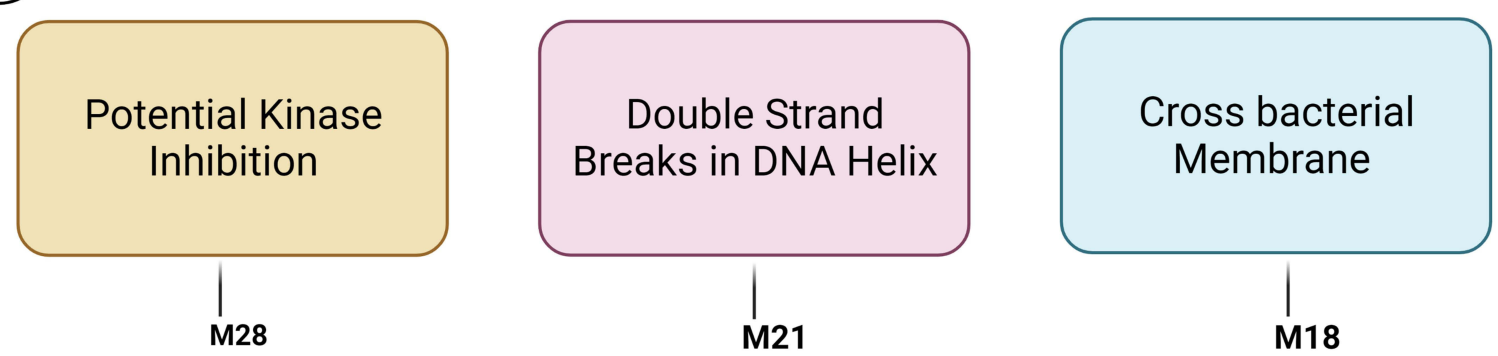

\section{3}

Anti-Inflammatory:
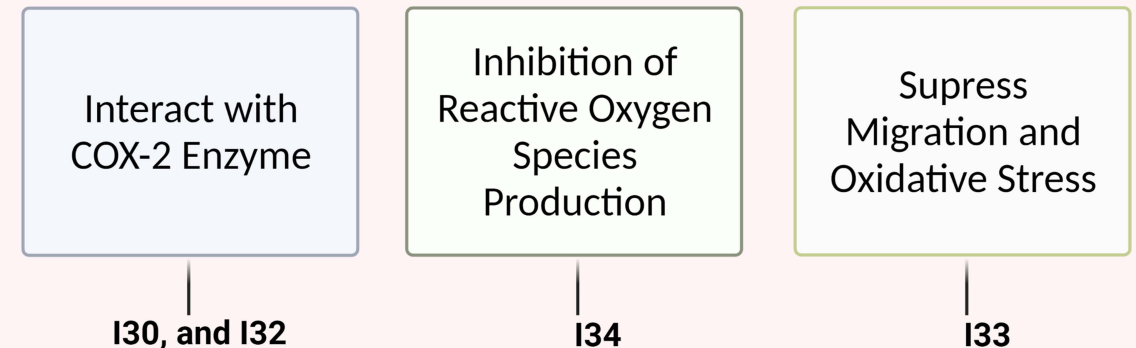

Inhibition of COX-1 and 2 ,

5-LOX, and

SPLA2-V

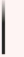

I31

Figure I Proposed mechanisms for imidazole derivatives. 
Table 8 Target Prediction of Imidazole Derivatives as Anti-Microbial

\begin{tabular}{|c|c|c|c|c|c|c|c|c|}
\hline $\begin{array}{l}\text { Compounds } \\
\text { Codes }\end{array}$ & $\begin{array}{l}\text { GPCR } \\
\text { Ligand }\end{array}$ & $\begin{array}{c}\text { Ion Channel } \\
\text { Modulator }\end{array}$ & $\begin{array}{l}\text { Kinase } \\
\text { Inhibitor }\end{array}$ & $\begin{array}{c}\text { Nuclear } \\
\text { Receptor } \\
\text { Ligand }\end{array}$ & $\begin{array}{l}\text { Protease } \\
\text { Inhibitor }\end{array}$ & $\begin{array}{l}\text { Enzyme } \\
\text { Inhibitor }\end{array}$ & Reported Target & Reference \\
\hline \multicolumn{9}{|c|}{ Imidazole Derivatives as Anti-microbial } \\
\hline MI8 & -0.10 & -0.48 & -0.21 & -0.46 & -0.27 & -0.19 & ND & [30] \\
\hline MI9 & 0.34 & 0.22 & 0.03 & 0.06 & 0.08 & 0.29 & ND & {$[31]$} \\
\hline M20 & 0.36 & 0.15 & 0.22 & 0.04 & -0.14 & 0.22 & ND & [31] \\
\hline M2I & 0.01 & -0.53 & -0.35 & -0.54 & -0.25 & 0.04 & $\begin{array}{l}\text { Double strand DNA } \\
\text { helix breakage }\end{array}$ & [32] \\
\hline M22 & -2.04 & -3.48 & -2.85 & -3.16 & -1.60 & -2.52 & ND & [33] \\
\hline M23 & -0.62 & -0.89 & -0.62 & -0.77 & -0.62 & -0.57 & ND & [34] \\
\hline M24 & 0.05 & 0.07 & 0.04 & -0.28 & -0.41 & 0.00 & ND & [35] \\
\hline M25 & 0.20 & 0.13 & 0.18 & -0.19 & -0.28 & 0.11 & ND & [37] \\
\hline M26 & 0.31 & 0.12 & 0.17 & 0.12 & -0.02 & 0.61 & CYP5I & [36] \\
\hline M27 & -0.89 & -1.48 & -0.30 & -1.93 & -1.54 & -0.67 & Kinase inhibitor & [37] \\
\hline M28 & -0.27 & 0.08 & -0.43 & -0.51 & -0.28 & -0.18 & ND & [38] \\
\hline M29 & -0.12 & -0.26 & -0.11 & 0.27 & -0.44 & 0.10 & ND & [39] \\
\hline
\end{tabular}

Table 9 The Target Prediction of Imidazole Derivatives as Anti-Inflammatory

\begin{tabular}{|c|c|c|c|c|c|c|c|c|}
\hline $\begin{array}{l}\text { Compounds } \\
\text { Codes }\end{array}$ & $\begin{array}{l}\text { GPCR } \\
\text { Ligand }\end{array}$ & $\begin{array}{c}\text { Ion Channel } \\
\text { Modulator }\end{array}$ & $\begin{array}{l}\text { Kinase } \\
\text { Inhibitor }\end{array}$ & $\begin{array}{l}\text { Nuclear } \\
\text { Receptor } \\
\text { Ligand }\end{array}$ & $\begin{array}{l}\text { Protease } \\
\text { Inhibitor }\end{array}$ & $\begin{array}{l}\text { Enzyme } \\
\text { Inhibitor }\end{array}$ & $\begin{array}{l}\text { Reported } \\
\text { Target }\end{array}$ & Reference \\
\hline \multicolumn{9}{|c|}{ Imidazole Derivatives as Anti-inflammatory } \\
\hline 130 & 0.42 & 0.32 & 0.67 & -0.10 & 0.12 & 0.24 & COX-2 enzyme & {$[45]$} \\
\hline$|3|$ & 0.17 & 0.08 & 0.48 & -0.23 & -0.25 & 0.32 & $\begin{array}{c}\text { COX-I,2 } \\
\text { 5-LOX, sPLA2-V } \\
\text { Inhibition }\end{array}$ & [50] \\
\hline 132 & -0.12 & -0.55 & -0.27 & -0.56 & -0.61 & -0.24 & COX-2 enzyme & [47] \\
\hline 133 & 0.05 & -0.06 & -0.19 & 0.02 & -0.24 & 0.21 & $\begin{array}{c}\text { p65 } \\
\text { NF-KB }\end{array}$ & [49] \\
\hline 134 & 0.64 & 0.15 & 0.26 & 0.03 & 0.28 & 0.72 & $N F-\kappa B$ & [48] \\
\hline 135 & 0.05 & 0.07 & 0.04 & -0.28 & -0.41 & 0.00 & ND & [35] \\
\hline 136 & 0.21 & 0.12 & 0.18 & -0.15 & -0.29 & 0.16 & ND & [35] \\
\hline 137 & -0.13 & 0.09 & 0.08 & -0.69 & -0.44 & -0.07 & ND & [44] \\
\hline 138 & -0.10 & -0.57 & -0.58 & -054 & -0.50 & -0.23 & ND & [46] \\
\hline 139 & -0.11 & -0.19 & 0.07 & -0.36 & -0.23 & -0.14 & ND & [5I] \\
\hline
\end{tabular}


in vitro testing using murine cell lines which could greatly influence the translation of data into the human biological system. The use of human cells, in-vivo models, and/or more complex in vitro 3D cultures that mimic the biological system could accelerate the development of these agents into the clinic. In summary, the current reported literature in imidazole core scaffold demonstrated potential therapeutic values that suggest further development and optimization in this area is required to discover novel and potent drug candidates.

\section{Abbreviations}

A375, Human Melanoma Cells; A549, Lung Cancer Cells; ADME, Absorption, Distribution, Metabolism, and Excretion; ASPC-1, pancreatic cancer cells; B16, Mouse Melanoma Cells; BBB, Blood-Brain Barrier; CDK6, Cyclin-Dependent Kinase 6; CNE-1, Nasopharyngeal Carcinoma; COX-1, cyclooxygenase-1; COX-2, cyclooxygenase-2; CTX, Cyclophosphamide; CYP2C19, Cytochrome P 450 2C19; CYP3A4, Cytochrome P 450 3A4; EAT, Ehrlich Ascites Tumor; EAT, Ehrlich Ascites Tumor; ERs, Estrogen Receptors; ESBL, Extended Spectrum Beta-Lactamases; FAK, Focal Adhesion Kinase; Flavus, Aspergillus flavus; GI, Gastrointestinal; GPCR, G protein Coupled Receptors; GSK-3 $\beta$, Glycogen Synthase Kinase 3 beta; H. oryzae, Hirschmanniella oryzae; HBA, Hydrogen Bond Acceptor; HBD, Hydrogen Bond Donor; HCT-116, Colon Cancer Cells; HEK 293, Kidney Cancer Cells; HL-60, Human Myeloid Leukemia Cells; HUVECS, Human Umbilical Vein Endothelial Cells; K562, Human Myeloid Leukemia Cells; Log P, Lipophilicity; Log S, Solubility; MCF-7, Breast Cancer Cells; Mcl-1, Myeloid Cell Leukemia 1; MDA-MB-231, Brest; MIC, Minimum Inhibitory Concentration; MPO, myeloperoxidase; MRSA, Methicillin-Resistance Staphylococcus Aureus; MW, Molecular Weight; NCI-60, National Cancer Institute- 60; NF- $\mathrm{B}$, Nuclear Factor Kappa B Niger, Aspergillus Niger; NSAID, Nonsteroidal Antiinflammatory Drugs; PANC-1, human pancreatic cancer cell line; PC-3, Prostate Cancer Cells; ROF, Rule of five; ROS, reactive oxygen species; S. Typhimurium, Salmonella typhimurium; SH-SY5Y, Neuroblastoma Cells; SMCS, Smooth Muscle Cells; subtilis, Bacillus subtilis; T. cruzi, Trypanosoma cruzi; T. vaginalis, Trichomonas vaginalis; T. viridae, Trichoderma viridae; U87-MG, Brain Cancer Cells; VRE, VancomycinResistant Enterococci.

\section{Acknowledgments}

The authors want to express their sincerest gratitude to the College of Pharmacy (COP) at King Saud bin Abdulaziz University for Health Sciences (KSAU-HS) for their continued support.

\section{Funding}

The authors acknowledge financial support from King Abdullah International Medical Research Center (KAIMRC), Ministry of National Guard Health Affairs, Riyadh, Kingdom of Saudi Arabia. Grant \# (SP20.441.R).

\section{Disclosure}

The authors declare no conflicts of interest for this work.

\section{References}

1. Sherer C, Snape TJ. Heterocyclic scaffolds as promising anticancer agents against tumours of the central nervous system: exploring the scope of indole and carbazole derivatives. Eur J Med Chem. 2015;97:552-560. doi:10.1016/j.ejmech.2014.11.007

2. Molina P, Tárraga A, Otón F. Imidazole derivatives: a comprehensive survey of their recognition properties. Org Biomol Chem. 2012;10 (9):1711-1724. doi:10.1039/c2ob06808g

3. Gaba M, Mohan C. Development of drugs based on imidazole and benzimidazole bioactive heterocycles: recent advances and future directions. Med Chem Res. 2016;25(2):173-210.

4. Institute NC. Cancer statistics; 2020. Available from: https://www.can cer.gov/about-cancer/understanding/statistics. Accessed July 20, 2021.

5. UK CR. Worldwide cancer statistics; 2018. Available from: https:// www.cancerresearchuk.org/health-professional/cancer-statistics /worldwide-cancer\#heading-One. Accessed July 20, 2021.

6. Institute NC. What is cancer?; 2015. Available from: https://www. cancer.gov/about-cancer/understanding/what-is-cancer. Accessed July 20, 2021.

7. Pérez-Herrero E, Fernández-Medarde A. Advanced targeted therapies in cancer: drug nanocarriers, the future of chemotherapy. Eur J Pharm Biopharm. 2015;93:52-79.

8. Ali R, Mirza Z, Ashraf GM, et al. New anticancer agents: recent developments in tumor therapy. Anticancer Res. 2012;32 (7):2999-3005.

9. Baviskar AT, Madaan C, Preet R, et al. N-fused imidazoles as novel anticancer agents that inhibit catalytic activity of topoisomerase ii $\alpha$ and induce apoptosis in G1/S phase. J Med Chem. 2011;54 (14):5013-5030. doi:10.1021/jm200235u

10. Zhao F, Lu W, Su F, et al. Synthesis and potential antineoplastic activity of dehydroabietylamine imidazole derivatives. MedChem Comm. 2018;9 (12):2091-2099. doi:10.1039/C8MD00487K

11. Chen J, Wang Z, Lu Y, Dalton JT, Miller DD, Li W. Synthesis and antiproliferative activity of imidazole and imidazoline analogs for melanoma. Bioorg Med Chem Lett. 2008;18(11):3183-3187. doi:10.1016/j.bmcl.2008.04.073

12. Dao P, Smith N, Tomkiewicz-Raulet C, et al. Design, synthesis, and evaluation of novel imidazo[1,2-a][1,3,5]triazines and their derivatives as focal adhesion kinase inhibitors with antitumor activity. J Med Chem. 2015;58(1):237-251. doi:10.1021/jm500784e

13. Sarkarzadeh H, Miri R, Firuzi O, et al. Synthesis and antiproliferative activity evaluation of imidazole-based indeno[1,2-b]quinoline-9,11dione derivatives. Arch Pharm Res. 2013;36(4):436-447. doi:10.1007/s12272-013-0032-7 
14. Roopashree R, Mohan CD, Swaroop TR, Jagadish S, Rangappa KS. Synthesis, characterization and in vivo biological evaluation of novel benzimidazoles as potential anticancer agents. Asian J Pharm Clin Res. 2014;7(5):309-313.

15. Alkahtani HM, Abbas AY, Wang S. Synthesis and biological evaluation of benzo[d]imidazole derivatives as potential anti-cancer agents. Bioorg Med Chem Lett. 2012;22(3):1317-1321. doi:10.1016/j. bmcl.2011.12.088

16. Chung K-H, Hong S-Y, You H-J, Park R-E, Ryu C-K. Synthesis and biological evaluation of 5-arylamino-1H-benzo[d]imidazole4,7-diones as inhibitor of endothelial cell proliferation. Bioorg Med Chem. 2006;14(17):5795-5801. doi:10.1016/j.bmc.2006.05.059

17. Xue N, Yang X, Wu R, et al. Synthesis and biological evaluation of imidazol-2-one derivatives as potential antitumor agents. Bioorg Med Chem. 2008;16(5):2550-2557. doi:10.1016/j.bmc.2007.11.048

18. Meenakshisundaram S, Manickam M, Pillaiyar T. Exploration of imidazole and imidazopyridine dimers as anticancer agents: design, synthesis, and structure-activity relationship study. Arch Pharm (Weinheim). 2019;352(12):e1900011. doi:10.1002/ardp.201900011

19. Wu Q, Song Y, Liu R, et al. Synthesis, docking studies and antitumor activity of phenanthroimidazole derivatives as promising c-myc G-quadruplex DNA stabilizers. Bioorg Chem. 2020;102:104074.

20. Fan C, Zhong T, Yang H, et al. Design, synthesis, biological evaluation of 6-(2-amino-1H-benzo [d] imidazole-6-yl) quinazolin-4 $(3 \mathrm{H})$-one derivatives as novel anticancer agents with Aurora kinase inhibition. Eur J Med Chem. 2020;190:112108.

21. Komuraiah B, Ren Y, Xue M, et al. Design, synthesis and biological evaluation of benz-fused five-membered heterocyclic compounds as tubulin polymerization inhibitors with anticancer activities. Chem Biol Drug Des. 2021;97(5):1109-1116.

22. Hassan AY, El-Sebaey SA, El Deeb MA, Elzoghbi MS. Potential antiviral and anticancer effect of imidazoles and bridgehead imidazoles generated by HPV-Induced cervical carcinomas via reactivating the $\mathrm{P} 53 / \mathrm{pRb}$ pathway and inhibition of CA IX. J Mol Struct. 2021;1230:129865.

23. Ali EM, Abdel-Maksoud MS, Ammar UM, et al. Design, synthesis, and biological evaluation of novel imidazole derivatives possessing terminal sulphonamides as potential BRAFV600E inhibitors. Bioorg Chem. 2021;106:104508.

24. Al-Blewi F, Shaikh SA, Naqvi A, et al. Design and synthesis of novel imidazole derivatives possessing triazole pharmacophore with potent anticancer activity, and in silico ADMET with GSK-3 $\beta$ molecular docking investigations. Int J Mol Sci. 2021;22(3):1162.

25. Zhang M, Ding Y, Qin H-X, et al. One-pot synthesis of substituted pyrrole-imidazole derivatives with anticancer activity. Mol Divers. 2020;24:1177-1184.

26. Badiee P, Hashemizadeh Z. Opportunistic invasive fungal infections: diagnosis \& clinical management. Indian J Med Res. 2014;139 (2):195-204.

27. US NIoH. Understanding emerging and re-emerging infectious diseases; 2007. Available from: https://www.ncbi.nlm.nih.gov/ books/NBK20370/. Accessed July 20, 2021.

28. World Health Organization. Record number of countries contribute data revealing disturbing rates of antimicrobial resistance; 2020. Available from: https:/www.who.int/news/item/01-06-2020-recordnumber-of-countries-contribute-data-revealing-disturbing-rates-ofantimicrobial-resistance.

29. World Health Organization. Antimicrobial Resistance and Primary Health Care. World Health Organization; 2018.

30. Ansari KF, Lal C. Synthesis, physicochemical properties and antimicrobial activity of some new benzimidazole derivatives. Eur J Med Chem. 2009;44(10):4028-4033. doi:10.1016/j.ejmech.2009.04.037
31. Sharma S, Gangal S, Rauf A. Convenient one-pot synthesis of novel 2-substituted benzimidazoles, tetrahydrobenzimidazoles and imidazoles and evaluation of their in vitro antibacterial and antifungal activities. Eur J Med Chem. 2009;44(4):1751-1757. doi:10.1016/j. ejmech.2008.03.026

32. Pieczonka AM, Strzelczyk A, Sadowska B, Mlostoń G, Stączek P. Synthesis and evaluation of antimicrobial activity of hydrazones derived from 3-oxido-1H-imidazole-4-carbohydrazides. Eur J Med Chem. 2013;64:389-395. doi:10.1016/j.ejmech.2013.04.023

33. Al-Blewi FF, Almehmadi MA, Aouad MR, et al. Design, synthesis, ADME prediction and pharmacological evaluation of novel benzimidazole-1,2,3-triazole-sulfonamide hybrids as antimicrobial and antiproliferative agents. Chem Cent J. 2018;12(1):110. doi:10.1186/s13065-018-0479-1

34. Daraji DG, Rajani DP, Rajani SD, et al. Structure based design, synthesis, and biological evaluation of imidazole derivatives targeting dihydropteroate synthase enzyme. Bioorg Med Chem Lett. 2021;36:127819.

35. Husain A, Drabu S, Kumar N, Alam MM, Bawa S. Synthesis and biological evaluation of di- and tri-substituted imidazoles as safer anti-inflammatory-antifungal agents. $J$ Pharm Bioallied Sci. 2013;5 (2):154-161. doi:10.4103/0975-7406.111822

36. Saccoliti F, Madia VN, Tudino V, et al. Design, synthesis, and biological evaluation of new 1-(Aryl-1 H-pyrrolyl)(phenyl)methyl-1 H-imidazole derivatives as antiprotozoal agents. J Med Chem. 2019;62(3):1330-1347. doi:10.1021/acs.jmedchem.8b01464

37. Ramu D, Jain R, Kumar RR, et al. Design and synthesis of imidazolidinone derivatives as potent anti-leishmanial agents by bioisosterism. Arch Pharm. 2019;352(4):e1800290. doi:10.1002/ ardp. 201800290

38. Aguirre G, Boiani M, Cerecetto H, et al. Novel antiprotozoal products: imidazole and benzimidazole N-Oxide derivatives and related compounds. Arch Pharm. 2004;337(5):259-270. doi:10.1002/ ardp. 200300840

39. Adeyemi OS, Eseola AO, Plass W, et al. Imidazole derivatives as antiparasitic agents and use of molecular modeling to investigate the structure-activity relationship. Parasitol Res. 2020;119(6):1925-1941.

40. Chen L, Deng $\mathrm{H}$, Cui $\mathrm{H}$, et al. Inflammatory responses and inflammation-associated diseases in organs. Oncotarget. 2018;9 (6):7204-7218. doi:10.18632/oncotarget.23208

41. Silva VG, Silva RO, Damasceno SRB, et al. Anti-inflammatory and antinociceptive activity of epiisopiloturine, an imidazole alkaloid isolated from Pilocarpus microphyllus. $J$ Nat Prod. 2013;76 (6):1071-1077. doi:10.1021/np400099m

42. Youssef J, Novosad SA, Winthrop KL. Infection risk and safety of corticosteroid use. Rheum Dis Clin North Am. 2016;42(1):157-x. doi:10.1016/j.rdc.2015.08.004

43. Sostres C, Gargallo CJ, Arroyo MT, Lanas A. Adverse effects of non-steroidal anti-inflammatory drugs (NSAIDs, aspirin and coxibs) on upper gastrointestinal tract. Best Pract Res Clin Gastroenterol. 2010;24(2):121-132. doi:10.1016/j.bpg.2009.11.005

44. Achar KC, Hosamani KM, Seetharamareddy HR. In-vivo analgesic and anti-inflammatory activities of newly synthesized benzimidazole derivatives. Eur J Med Chem. 2010;45(5):2048-2054. doi:10.1016/j. ejmech.2010.01.029

45. Shankar B, Jalapathi P, Valeru A, Kishor Kumar A, Saikrishna B, Kudle K. Synthesis and biological evaluation of new 2-(6-alkylpyrazin-2-yl)-1H-benz[d]imidazoles as potent anti-inflammatory and antioxidant agents. Med Chem Res. 2017;26(9):1835-1846. doi:10.1007/s00044-017-1897-7

46. Shantharam C. Synthesis and SAR studies of potent antioxidant and anti-inflammatory activities of imidazole Derived Schiff base analogues. Biochem Anal Biochem. 2017;06:314. 
47. Katikireddy R, Kakkerla R, Krishna MPSM, Durgaiah G, Reddy YN, Satyanarayana M. Synthesis and biological evaluation of (E)-N'benzylidene-7-methyl-2-propyl-1H-benzo[d] imidazole-5-carbohydrazides as antioxidant, anti-inflammatory and analgesic agents. Heterocycl Comm. 2019;25(1):27-38. doi:10.1515/hc-2019-0009

48. Rocha TM, Machado NJ, de Sousa JAC, et al. Imidazole alkaloids inhibit the pro-inflammatory mechanisms of human neutrophil and exhibit anti-inflammatory properties in vivo. $J$ Pharm Pharmacol. 2019;71(5):849-859. doi:10.1111/jphp.13068

49. Nascimento M, Munhoz ACM, Theindl LC, et al. A novel tetrasubstituted imidazole as a prototype for the development of anti-inflammatory drugs. Inflammation. 2018;41(4):1334-1348. doi:10.1007/s10753-018-0782-y

50. Bukhari SN, Lauro G, Jantan I, et al. Anti-inflammatory trends of new benzimidazole derivatives. Future Med Chem. 2016;8 (16):1953-1967. doi:10.4155/fmc-2016-0062

51. Gaba M. Design, synthesis and biological evaluation of Novel 1, 2, 5-substituted benzimidazole derivatives as gastroprotective anti-inflammatory and analgesic agents. Med Chem (Los Angeles). 2015;5(2). doi:10.4172/2161-0444.1000243

52. Lipinski C, Lipinski CA. Lead- and drug-like compounds: the rule-of-five revolution. Drug Discov Today Technol. 2004;1:337-341. doi:10.1016/j.ddtec.2004.11.007

53. Di L, Kerns EH. Drug-Like Properties: Concepts, Structure, Design and Methods: From ADME to Toxicity Optimization. Amsterdam [i pozostale]: Elsevier - Academic Press; 2019.
54. Sharom FJ. ABC multidrug transporters: structure, function and role in chemoresistance. Pharmacogenomics. 2008;9(1):105-127. doi:10.2217/14622416.9.1.105

55. Arnott JA, Planey SL. The influence of lipophilicity in drug discovery and design. Expert Opin Drug Discov. 2012;7(10):863-875. doi: $10.1517 / 17460441.2012 .714363$

56. Daina A, Michielin O, Zoete V. SwissADME: a free web tool to evaluate pharmacokinetics, drug-likeness and medicinal chemistry friendliness of small molecules. Sci Rep. 2017;7(1):42717. doi:10.1038/srep42717

57. Noriega-Iribe E, Díaz-Rubio L, Estolano-Cobián A, et al. In vitro and in silico screening of 2,4,5-trisubstituted imidazole derivatives as potential xanthine oxidase and acetylcholinesterase inhibitors, antioxidant, and antiproliferative agents. Appl Sci. 2020;10(8):2889. doi:10.3390/app10082889

58. Abraham MH, Chadha HS, Mitchell RC. Hydrogen bonding. 33. Factors that influence the distribution of solutes between blood and brain. $J$ Pharm Sci. 1994;83(9):1257-1268. doi:10.1002/ jps.2600830915

59. Pajouhesh H, Lenz GR. Medicinal chemical properties of successful central nervous system drugs. NeuroRx. 2005;2(4):541-553.

60. Cheminformatics M; 2020. Available from: https://www.molinspira tion.com. Accessed July 20, 2021.
Drug Design, Development and Therapy

\section{Publish your work in this journal}

Drug Design, Development and Therapy is an international, peerreviewed open-access journal that spans the spectrum of drug design and development through to clinical applications. Clinical outcomes, patient safety, and programs for the development and effective, safe, and sustained use of medicines are a feature of the journal, which has also

\section{Dovepress}

been accepted for indexing on PubMed Central. The manuscript management system is completely online and includes a very quick and fair peer-review system, which is all easy to use. Visit http://www. dovepress.com/testimonials.php to read real quotes from published authors. 